\title{
LEVEL II SCOUR ANALYSIS FOR BRIDGE 8 (NEWFTH00010008) on TOWN HIGHWAY 1, crossing WARDSBORO BROOK, NEWFANE, VERMONT
}

Open-File Report 98-90

Prepared in cooperation with

VERMONT AGENCY OF TRANSPORTATION

and

FEDERAL HIGHWAY ADMINISTRATION

U.S. Department of the Interior U.S. Geological Survey

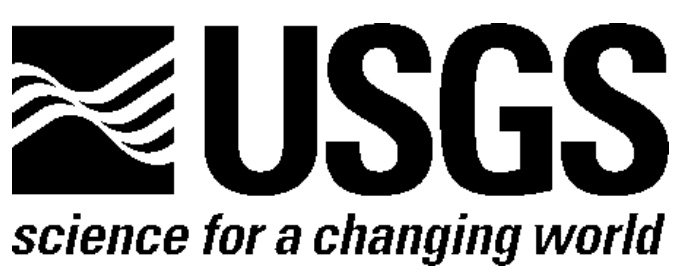




\section{LEVEL II SCOUR ANALYSIS FOR BRIDGE 8 (NEWFTH00010008) on TOWN HIGHWAY 1, crossing WARDSBORO BROOK, NEWFANE, VERMONT By EMILY C. WILD and JAMES R. DEGNAN}

U.S. Geological Survey Open-File Report 98-90

Prepared in cooperation with

VERMONT AGENCY OF TRANSPORTATION and

FEDERAL HIGHWAY ADMINISTRATION 


\title{
U.S. DEPARTMENT OF THE INTERIOR BRUCE BABBITT, Secretary
}

\author{
U.S. GEOLOGICAL SURVEY
}

Thomas J. Casadevall, Acting Director

For additional information write to:

District Chief

U.S. Geological Survey 361 Commerce Way

Pembroke, NH 03275-3718
Copies of this report may be purchased from:

U.S. Geological Survey

Branch of Information Services

Open-File Reports Unit

Box 25286

Denver, CO 80225-0286 


\section{CONTENTS}

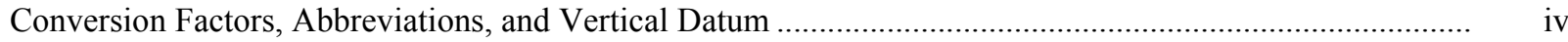

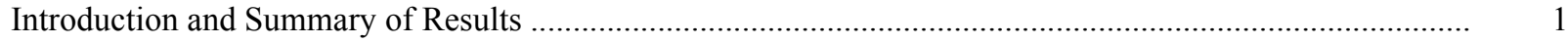

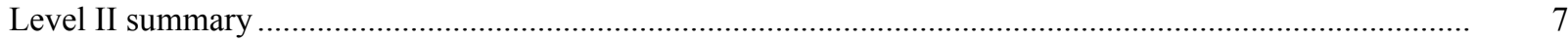

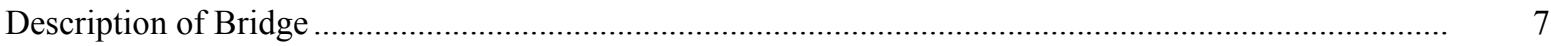

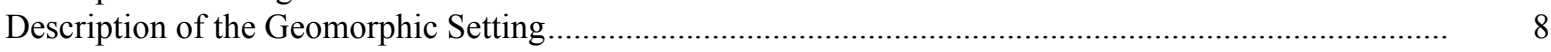

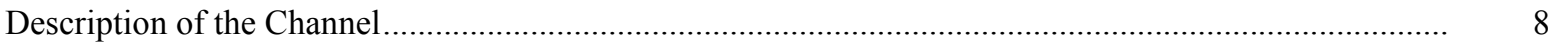

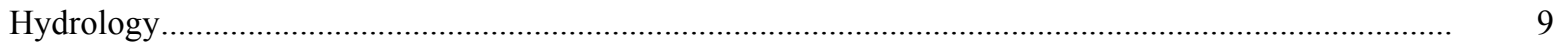

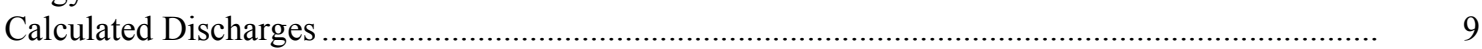

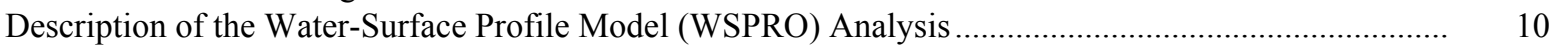

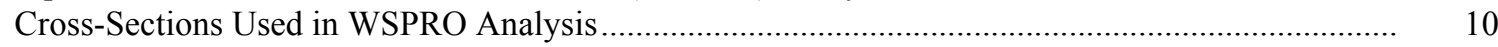

Data and Assumptions Used in WSPRO Model ........................................................................ 11

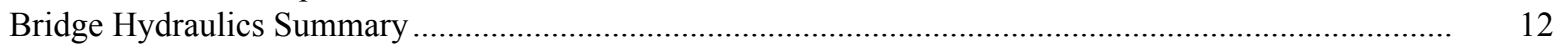

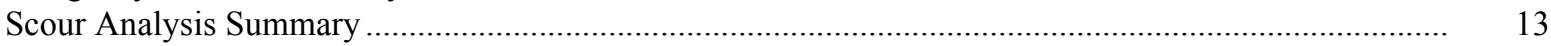

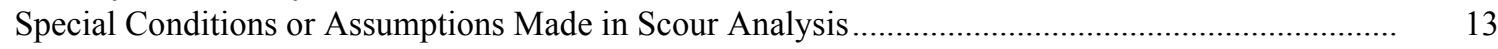

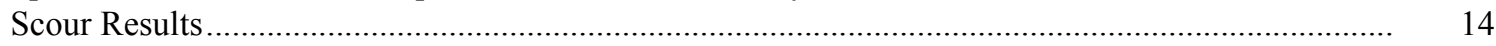

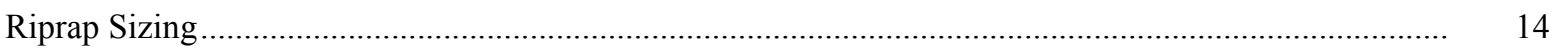

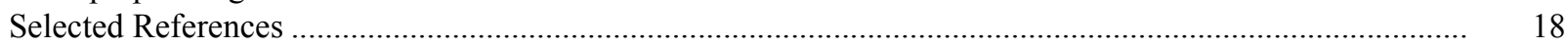

Appendices:

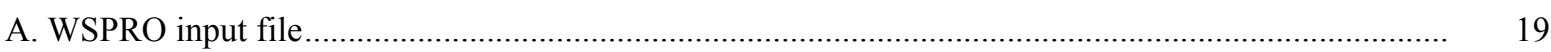

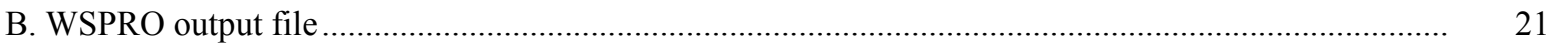

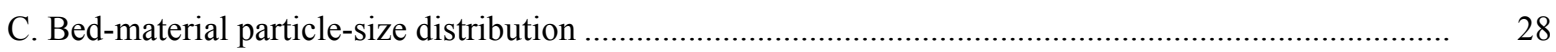

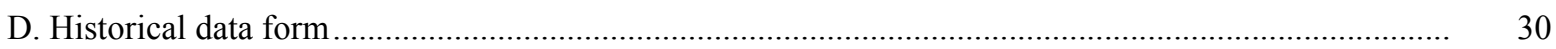

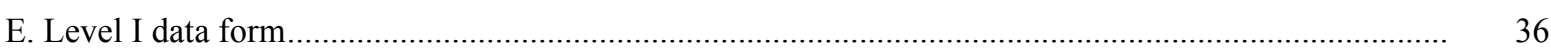

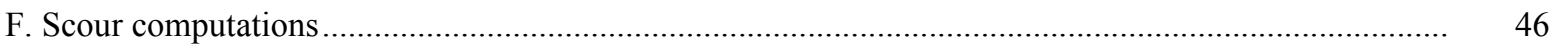

\section{FIGURES}

1. Map showing location of study area on two USGS 1:25,000 scale maps

2. Map showing location of study area on Vermont Agency of Transportation town highway map

3. Structure NEWFTH00010008 viewed from upstream (August 21, 1996)

4

4. Downstream channel viewed from structure NEWFTH00010008 (August 21, 1996).................................

5. Upstream channel viewed from structure NEWFTH00010008 (August 21, 1996)

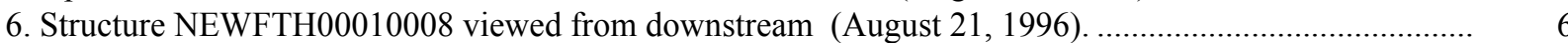

7. Water-surface profiles for the 100- and 500-year discharges at structure

NEWFTH00010008 on Town Highway 1, crossing Wardsboro Brook,

Newfane, Vermont.

8. Scour elevations for the 100- and 500-year discharges at structure

NEWFTH00010008 on Town Highway 1, crossing Wardsboro Brook,

Newfane, Vermont.

\section{TABLES}

1. Remaining footing/pile depth at abutments for the 100-year discharge at structure

NEWFTH00010008 on Town Highway 1, crossing Wardsboro Brook,

Newfane, Vermont

2. Remaining footing/pile depth at abutments for the 500-year discharge at structure

NEWFTH00010008 on Town Highway 1, crossing Wardsboro Brook,

Newfane, Vermont 


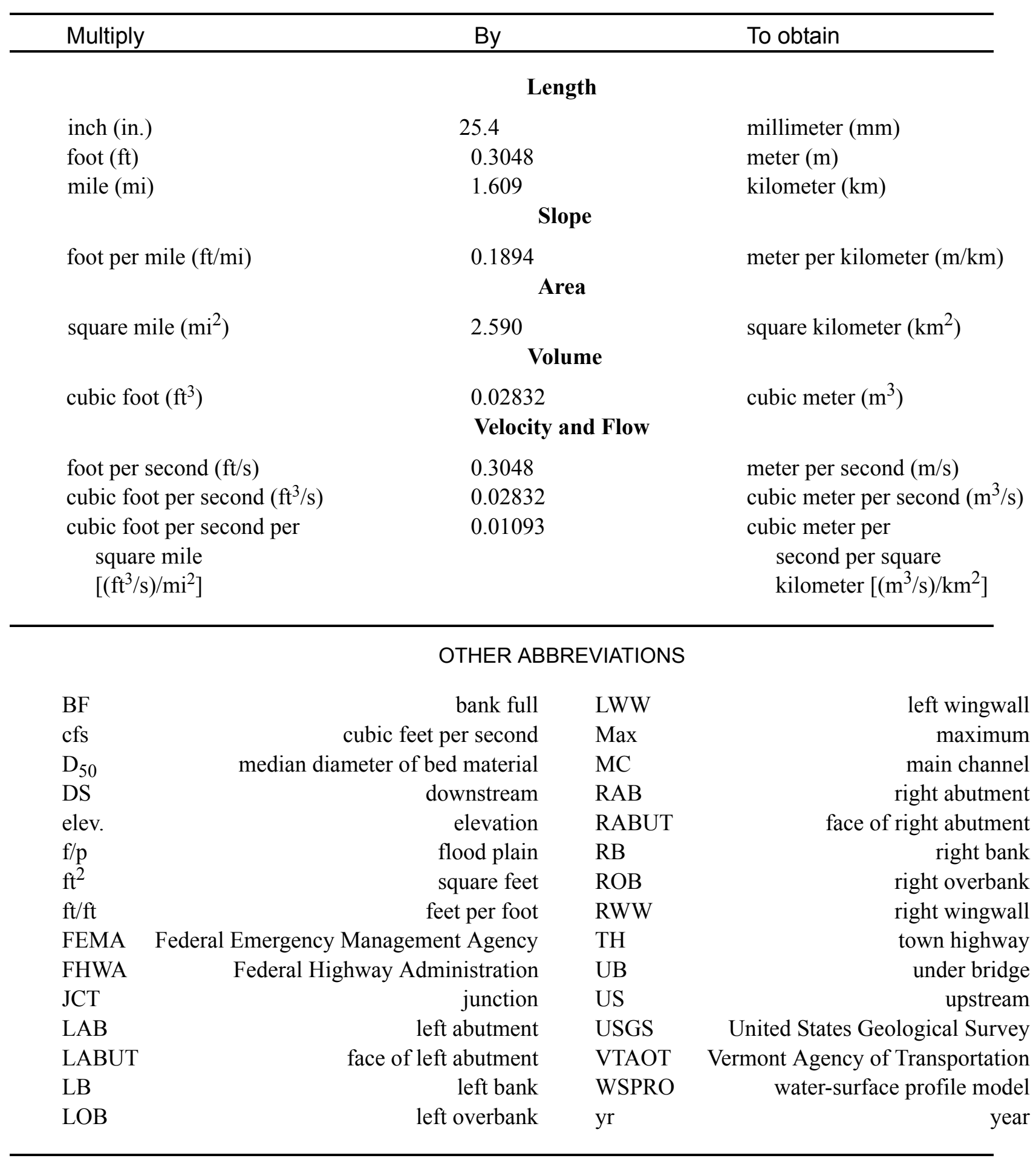

In this report, the words "right" and "left" refer to directions that would be reported by an observer facing downstream. Sea level: In this report, "sea level" refers to the National Geodetic Vertical Datum of 1929-- a geodetic datum derived from a general adjustment of the first-order level nets of the United States and Canada, formerly called Sea Level Datum of 1929.

In the appendices, the above abbreviations may be combined. For example, USLB would represent upstream left bank. 


\title{
LEVEL II SCOUR ANALYSIS FOR BRIDGE 8 (NEWFTH00010008) ON TOWN HIGHWAY 1, CROSSING WARDSBORO BROOK, NEWFANE, VERMONT
}

\author{
By Emily C. Wild and James R. Degnan
}

\section{INTRODUCTION AND SUMMARY OF RESULTS}

This report provides the results of a detailed Level II analysis of scour potential at structure NEWFTH00010008 on Town Highway 1 crossing Wardsboro Brook, Newfane, Vermont (figures 1-8). A Level II study is a basic engineering analysis of the site, including a quantitative analysis of stream stability and scour (Federal Highway Administration, 1993). Results of a Level I scour investigation also are included in appendix E of this report. A Level I investigation provides a qualitative geomorphic characterization of the study site. Information on the bridge, gleaned from Vermont Agency of Transportation (VTAOT) files, was compiled prior to conducting Level I and Level II analyses and is found in appendix D.

The site is in the New England Upland section of the New England physiographic province in southestern Vermont. The $6.91-\mathrm{mi}^{2}$ drainage area is in a predominantly rural and forested basin. In the vicinity of the study site, the surface cover is forest on the upstream right overbank and downstream left and right overbanks. The surface cover on the upstream left overbank is pasture.

In the study area, Wardsboro Brook has an incised, sinuous channel with a slope of approximately $0.02 \mathrm{ft} / \mathrm{ft}$, an average channel top width of $63 \mathrm{ft}$ and an average bank height of $9 \mathrm{ft}$. The channel bed material ranges from gravel to boulders with a median grain size $\left(\mathrm{D}_{50}\right)$ of $95.4 \mathrm{~mm}(0.313 \mathrm{ft})$. The geomorphic assessment at the time of the Level I and Level II site visit on August 21, 1996, indicated that the reach was stable.

The Town Highway 1 crossing of the Wardsboro Brook is a 32-ft-long, two-lane bridge consisting of a 26-foot concrete tee-beam span (Vermont Agency of Transportation, written communication, April 6, 1995). The opening length of the structure parallel to the bridge face is $26.7 \mathrm{ft}$. The bridge is supported by vertical, concrete abutments with wingwalls. The channel is skewed approximately 45 degrees to the computed opening while the openingskew-to-roadway is 45 degrees. 
A scour hole $1.0 \mathrm{ft}$ deeper than the mean thalweg depth was observed along the right abutment during the Level I assessment. Scour protection measures at the site included type-1 stone fill (less than 12 inches diameter) along the upstream right bank, and type-2 stone fill (less than 36 inches diameter) along the upstream left bank and the upstream ends of the upstream left and right wingwalls. A stone wall extends along the downstream right bank from the end of the downstream right wingwall. Additional details describing conditions at the site are included in the Level II Summary and appendices D and E.

Scour depths and recommended rock rip-rap sizes were computed using the general guidelines described in Hydraulic Engineering Circular 18 (Richardson and Davis, 1995) for the 100- and 500-year discharges. In addition, the incipient roadway-overtopping discharge was determined and analyzed as another potential worst-case scour scenario. Total scour at a highway crossing is comprised of three components: 1) long-term streambed degradation; 2) contraction scour (due to accelerated flow caused by a reduction in flow area at a bridge) and; 3 ) local scour (caused by accelerated flow around piers and abutments). Total scour is the sum of the three components. Equations are available to compute depths for contraction and local scour and a summary of the results of these computations follows.

Contraction scour for all modelled flows ranged from 0.1 to $3.9 \mathrm{ft}$. The worst-case contraction scour occurred at the 500-year discharge. Left abutment scour ranged from 11.1 to $12.9 \mathrm{ft}$. Right abutment scour ranged from 4.3 to $4.8 \mathrm{ft}$. The worst-case abutment scour occurred at the 500-year discharge. Additional information on scour depths and depths to armoring are included in the section titled "Scour Results". Scoured-streambed elevations, based on the calculated scour depths, are presented in tables 1 and 2. A cross-section of the scour computed at the bridge is presented in figure 8. Scour depths were calculated assuming an infinite depth of erosive material and a homogeneous particle-size distribution.

It is generally accepted that the Froehlich equation (abutment scour) gives "excessively conservative estimates of scour depths" (Richardson and Davis, 1995, p. 46). Usually, computed scour depths are evaluated in combination with other information including (but not limited to) historical performance during flood events, the geomorphic stability assessment, existing scour protection measures, and the results of the hydraulic analyses. Therefore, scour depths adopted by VTAOT may differ from the computed values documented herein. 


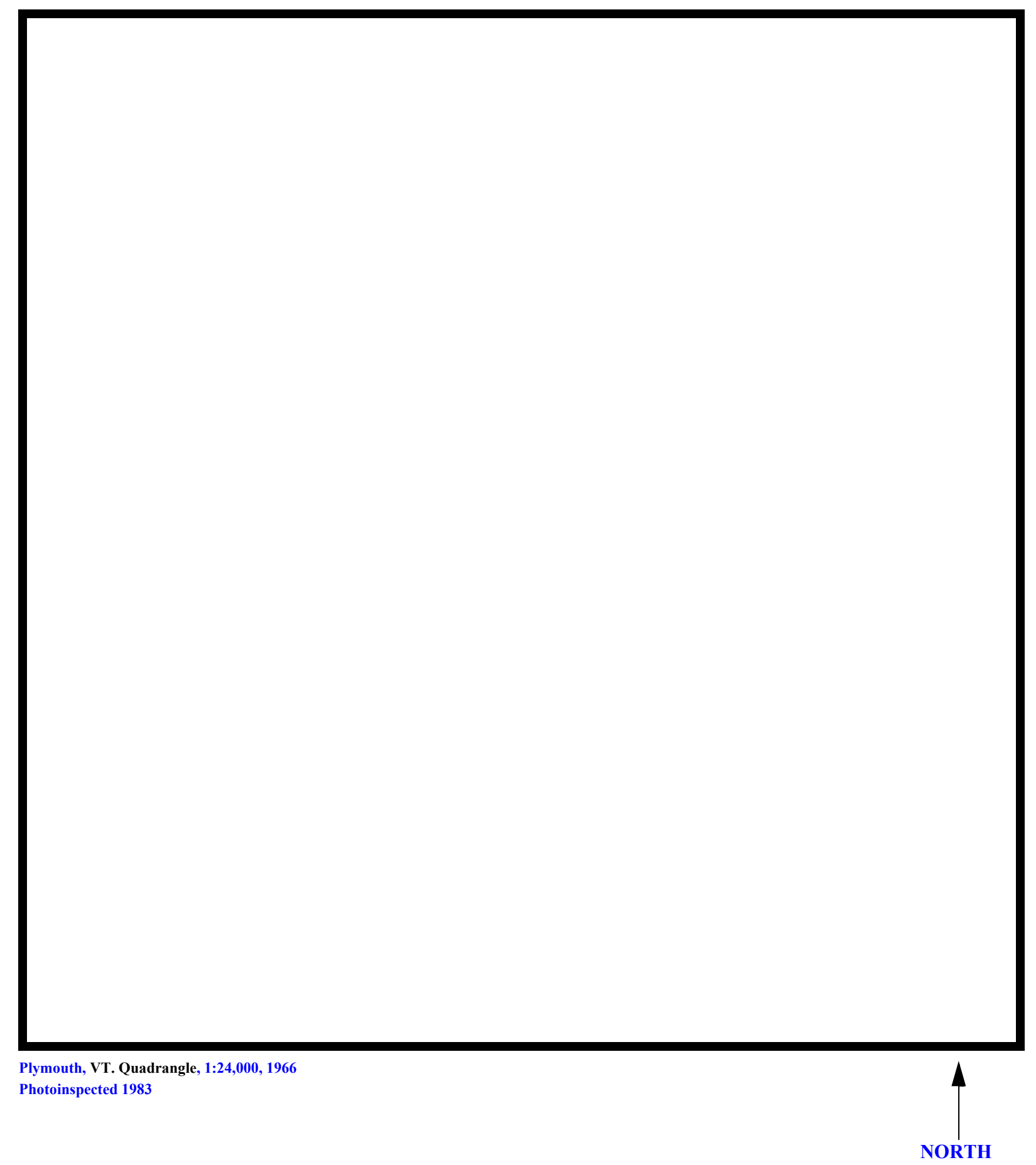

Figure 1. Location of study area on USGS 1:24,000 scale map. 
Figure 2. Location of study area on Vermont Agency of Transportation town highway map. 

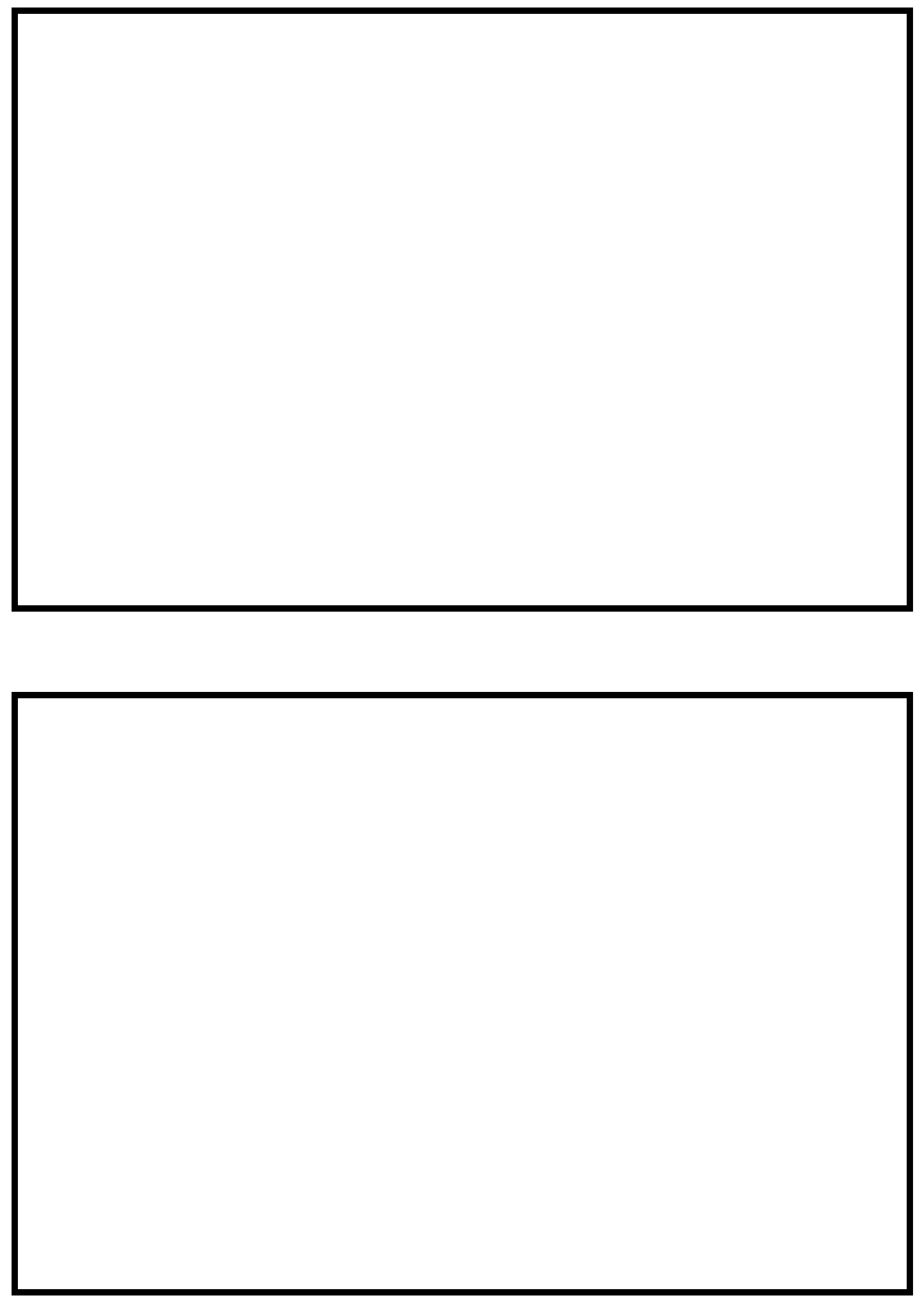

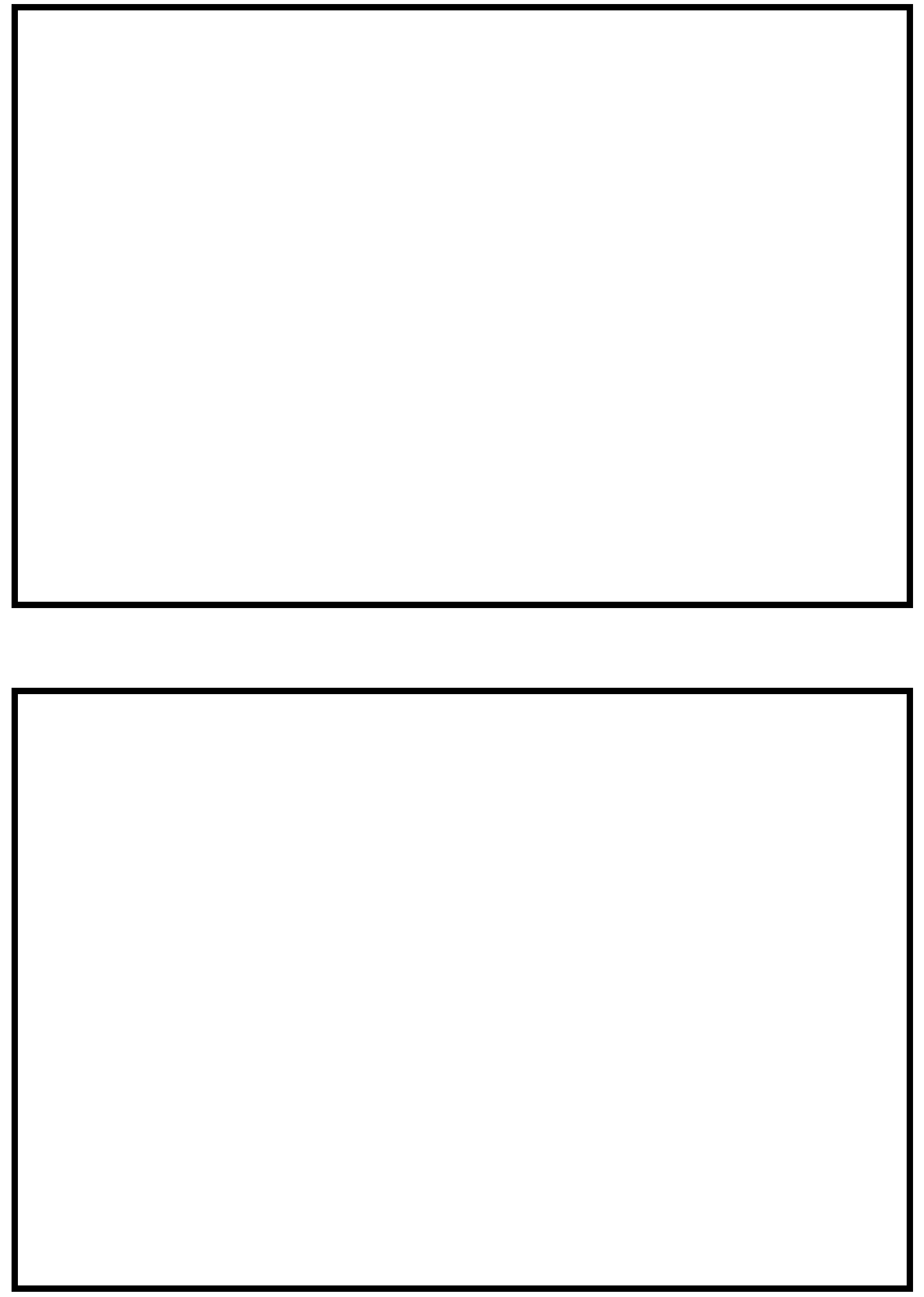


\section{LEVEL II SUMMARY}

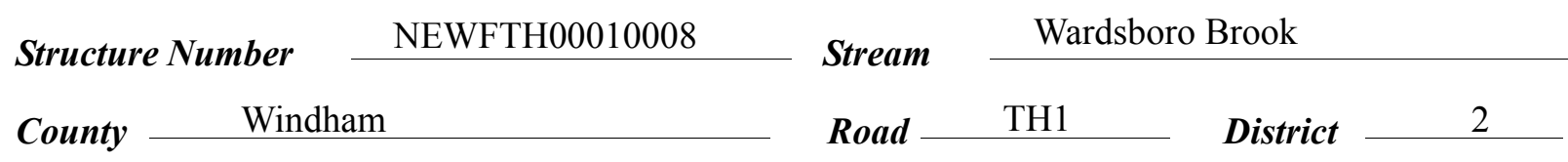

\section{Description of Bridge}

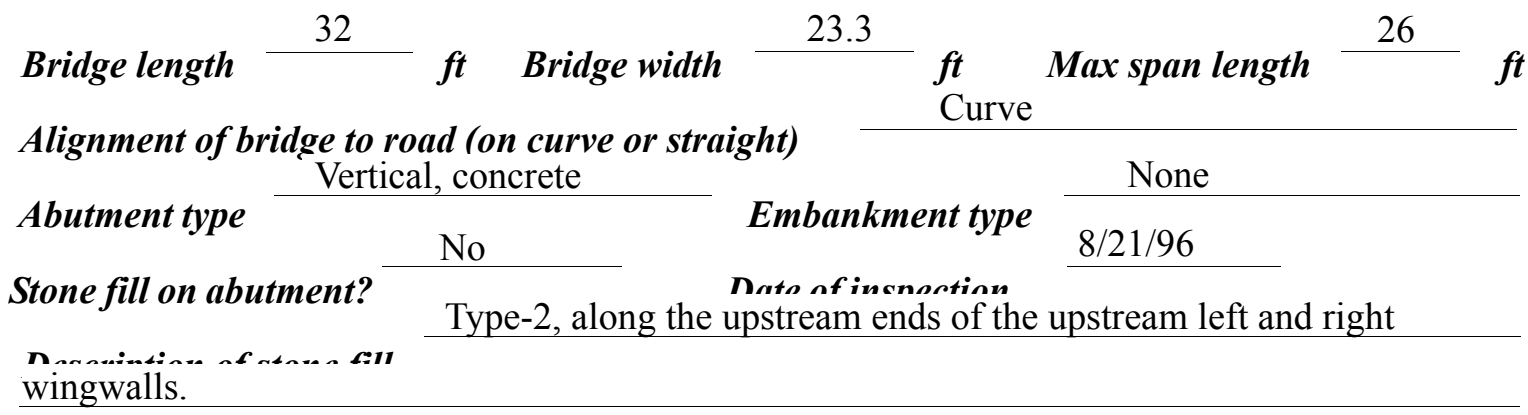

Abutments and wingwalls are concrete. There was a

one foot deep scour hole in front of the right abutment.

Yes

45

Is bridge skewed to flood flow according to No ' survey? Angle

Debris accumulation on bridge at time of Level I or Level II site visit:

\begin{tabular}{|c|c|c|c|}
\hline & $\begin{array}{c}\text { Date of insnortion } \\
8 / 21 / 96 \\
\end{array}$ & $\begin{array}{l}\text { Percent of rhmunal } \\
\text { blocked inortzontatly }\end{array}$ & $\begin{array}{l}\text { Percent of } 0 \\
\text { blocked verticatty }\end{array}$ \\
\hline Level I & $8 / 21 / 96$ & 0 & 0 \\
\hline $\begin{array}{l}\text { Level II } \\
\text { upstream. }\end{array}$ & \multicolumn{3}{|c|}{ High. There was some debris accumulation within the channel } \\
\hline
\end{tabular}

No features that may affect flow were observed during the 8/21/96 inspection.

Doscriho any, foaturos noar ar at tho hridoo that mav, affort flou, (includo ahsorvation dato) 


\section{Description of the Geomorphic Setting}

General topography The channel is located within a narrow irregular flood plain with steep valley walls.

Geomorphic conditions at bridge site: downstream (DS), upstream (US)

Date of inspection $\quad 8 / 21 / 96$

DS left: $\quad$ Moderately sloped overbank

DS right: $\quad$ Steep valley wall

US left: $\quad$ Steep valley wall

US right: $\quad$ Steep valley wall

\section{Description of the Channel}

$\begin{array}{lllll} & 63 & \text { Average top width } & \text { Average depth } & 9 \\ & \text { Gravel/Cobbles } & \text { Cobbles/Boulders }\end{array}$

Predominant bed material Bank material Sinuous but stable

with non-alluvial channel boundaries and a narrow flood plain.

$8 / 21 / 96$

Vegetative co 1 Trees and brush

DS left: $\quad$ Trees and brush

DS right: $\quad$ Pasture and trees

US left: $\quad$ Trees and brush

US right: $\quad$ Yes

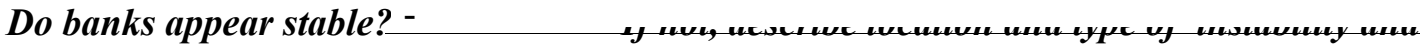

date of observatton.

noted during the assessment of 8/21/96.

Describe any obstructions in channel and date of observation. 


\title{
Hydrology
}

Drainage area $\quad 6.9 \quad \mathrm{mi}^{2}$

Percentage of drainage area in physiographic provinces: (approximate)

Physiographic province/section New England/New England Upland
Percent of drainage area 100

\begin{abstract}
Is drainage area considered rural or urban? Rural Describe any significant urbanization: None.
\end{abstract}

Is there a

Is there a USGS gage on the stream of interest?

USGS gage description ---

USGS gage number

Gage drainage area $\mathrm{mi}^{2}$

No

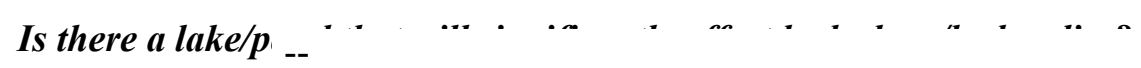

\section{Calculated Discharges $\quad 2,350$ \\ Q100 $\quad \mathrm{ft}^{3} / \mathrm{s}$}

The 100- and 500-year discharges are the median

values taken from empirical flood fregquency curves (Benson, 1962; Johnson and Tasker, 1974;

FHWA, 1983; Potter, 1957a\&b; Talbot, 1887). The 500-year discharge was extrapolated. 


\section{Description of the Water-Surface Profile Model (WSPRO) Analysis}

Datum for WSPRO analysis (USGS survey, sea level, VTAOT plans)

USGS survey

Datum tie between USGS survey and VTAOT plans

None

Description of reference marks used to determine USGS datum. $\quad$ RM1 is a chiseled X on top of the downstream end of the downstream right wingwall (elev. $498.32 \mathrm{ft}$, arbitrary survey

datum). RM2 is a chiseled X on top of the upstream left wingwall (elev. $498.93 \mathrm{ft}$, arbitrary

survey datum).

\section{Cross-Sections Used in WSPRO Analysis}

\begin{tabular}{|c|c|c|c|}
\hline${ }^{1}$ Cross-section & $\begin{array}{c}\text { Section } \\
\text { Reference } \\
\text { Distance } \\
\text { (SRD) in feet }\end{array}$ & $\begin{array}{c}{ }^{2} \text { Cross-section } \\
\text { development }\end{array}$ & Comments \\
\hline EXITX & -35 & 1 & Exit section \\
\hline FULLV & 0 & 2 & $\begin{array}{l}\text { Downstream Full-valley } \\
\text { section (Templated from } \\
\text { EXITX) }\end{array}$ \\
\hline BRIDG & 0 & 1 & Bridge section \\
\hline RDWAY & 17 & 1 & Road Grade section \\
\hline APPRO & 53 & 2 & $\begin{array}{l}\text { Modelled Approach sec- } \\
\text { tion (Templated from } \\
\text { APTEM) }\end{array}$ \\
\hline APTEM & 71 & 1 & $\begin{array}{l}\text { Approach section as sur- } \\
\text { veyed (Used as a tem- } \\
\text { plate) }\end{array}$ \\
\hline
\end{tabular}

${ }^{1}$ For location of cross-sections see plan-view sketch included with Level I field form, Appendix E. For more detail on how cross-sections were developed see WSPRO input file. 


\section{Data and Assumptions Used in WSPRO Model}

Hydraulic analyses of the reach were done by use of the Federal Highway Administration's WSPRO step-backwater computer program (Shearman and others, 1986, and Shearman, 1990). The analyses reported herein reflect conditions existing at the site at the time of the study. Furthermore, in the development of the model it was necessary to assume no accumulation of debris or ice at the site. Results of the hydraulic model are presented in the Bridge Hydraulic Summary, appendix B, and figure 7.

Channel roughness factors (Manning's " $n$ ") used in the hydraulic model were estimated using field inspections at each cross section following the general guidelines described by Arcement and Schneider (1989). Final adjustments to the values were made during the modelling of the reach. Channel " $\mathrm{n}$ " values for the reach ranged from 0.040 to 0.073 , and overbank " $\mathrm{n}$ " values ranged from 0.038 to 0.050 .

Normal depth at the exit section (EXITX) was assumed as the starting water surface. This depth was computed by use of the slope-conveyance method outlined in the user's manual for WSPRO (Shearman, 1990). The slope used was $0.0240 \mathrm{ft} / \mathrm{ft}$, which was estimated from the topographic map (U.S. Geological Survey, 1984a).

The surveyed approach section (APTEM) was moved along the approach channel slope $(0.0285 \mathrm{ft} / \mathrm{ft})$ to establish the modelled approach section (APPRO), one bridge length upstream of the upstream face as recommended by Shearman and others (1986). This location provides a consistent method for determining scour variables. 


\section{Bridge Hydraulics Summary}

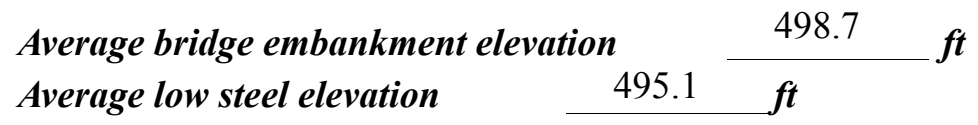

$$
\text { 100-year discharge } \quad 1,690 \quad \mathrm{ft}^{3} / \mathrm{s}
$$

Water-surface elevation in bridge opening $\quad 495.1 \quad f t$

Road overtopping? ___ Yes Discharge over road__ $400 \quad \mathrm{ft}^{3} / \mathrm{s}$

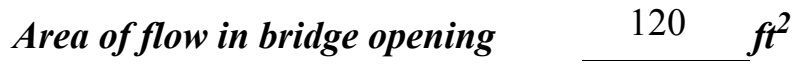

Average velocity in bridge opening $10.8 \mathrm{ft} / \mathrm{s}$

$\begin{array}{llll}\text { Maximum WSPRO tube velocity at bridge } & 13.6 \mathrm{ft} / \mathrm{s}\end{array}$

Water-surface elevation at Approach section with bridge 499.9

Water-surface elevation at Approach section without bridge $\quad 495.7$

Amount of backwater caused by bridge

$4.2 i$

500-year discharge $\quad 2,350 \quad \boldsymbol{f t}^{3} / \mathrm{s}$

Water-surface elevation in bridge opening

$495.1 \mathrm{ft}$

Road overtopping? ___ Yes Discharge over road __ $712,{ }^{3} / \mathbf{s}$

Area of flow in bridge opening $\quad 120 \quad \mathrm{ft}^{2}$

Average velocity in bridge opening $\quad 13.7 \mathrm{ft} / \mathrm{s}$

Maximum WSPRO tube velocity at bridge 17.3 , 's

Water-surface elevation at Approach section with bridge

Water-surface elevation at Approach section without bridge

Amount of backwater caused by bridge $\quad 3.7$.t

500.3

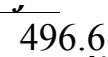

Incipient overtopping discharge $\quad 1,120 \mathrm{ft}^{3} / \mathrm{s}$

Water-surface elevation in bridge opening $495.1 \quad$ it

Area of flow in bridge opening

Average velocity in bridge opening

$120 \quad f^{2}$

$t^{2}$

Maximum WSPRO tube velocity at bridge

$9.4 \mathrm{ft} / \mathrm{s}$

Water-surface elevation at Approach section with bridge

Water-surface elevation at Approach section without bridge

Amount of backwater caused by bridge $\quad 3.5$ it

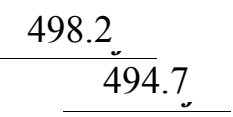




\section{Scour Analysis Summary}

\section{Special Conditions or Assumptions Made in Scour Analysis}

Scour depths were computed using the general guidelines described in Hydraulic Engineering Circular 18 (Richardson and Davis, 1995). Scour depths were calculated assuming an infinite depth of erosive material and a homogeneous particle-size distribution. The results of the scour analyses for the 100- and 500-year discharges are presented in tables 1 and 2 and the scour depths are shown graphically in figure 8 .

At this site, the 100-year and incipient roadway-overtopping discharges resulted in unsubmerged orifice flow, while the 500-year discharge resulted in submerged orifice flow. Contraction scour at bridges with orifice flow is best estimated by use of the Chang pressureflow scour equation (oral communication, J. Sterling Jones, October 4, 1996). Thus, contraction scour for these discharges was computed by use of the Chang equation (Richardson and Davis, 1995, p. 145-146). The streambed armoring depths computed suggest that armoring will not limit the depth of contraction scour.

For comparison, contraction scour was computed by use of the Laursen clear-water contraction scour equation and the Umbrell pressure-flow equation (Richardson and Davis, 1995, p. 144). Furthermore, for those discharges resulting in unsubmerged orifice flow, contraction scour was computed by substituting estimates for the depth of flow at the downstream bridge face in the contraction scour equations. The additional contraction scour computations are presented in appendix F.

Abutment scour was computed by use of the Froehlich equation (Richardson and Davis, 1995, p. 48, equation 28). Variables for the Froehlich equation include the Froude number of the flow approaching the embankments, the length of the embankment blocking flow, and the depth of flow approaching the embankment less any roadway overtopping. 


\section{Scour Results}
100-yr discharge 500-yr discharge
Incipient overtopping (Scour depths in feet)

Contraction scour:

Main channel

Live-bed scour

Clear-water scour

Depth to armoring

Left overbank

Right overbank
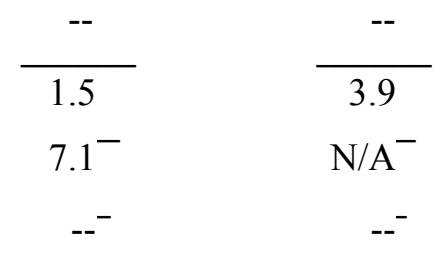

$\frac{--}{0.1}$

$10.7^{-}$

$\mathrm{N} / \mathrm{A}^{-}$

$--$

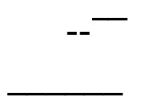

$--$

$--$

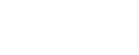

Local scour:

Abutment scour

11.6

12.9

11.1

Left abutment

4.7-

$4.8-$

4.3-

\section{Right abutment}

Pier scour

Pier 1

Pier 2

Pier 3

Abutments:

Left abutment

Right abutment

Piers:

Pier 1

Pier 2

\section{Riprap Sizing}

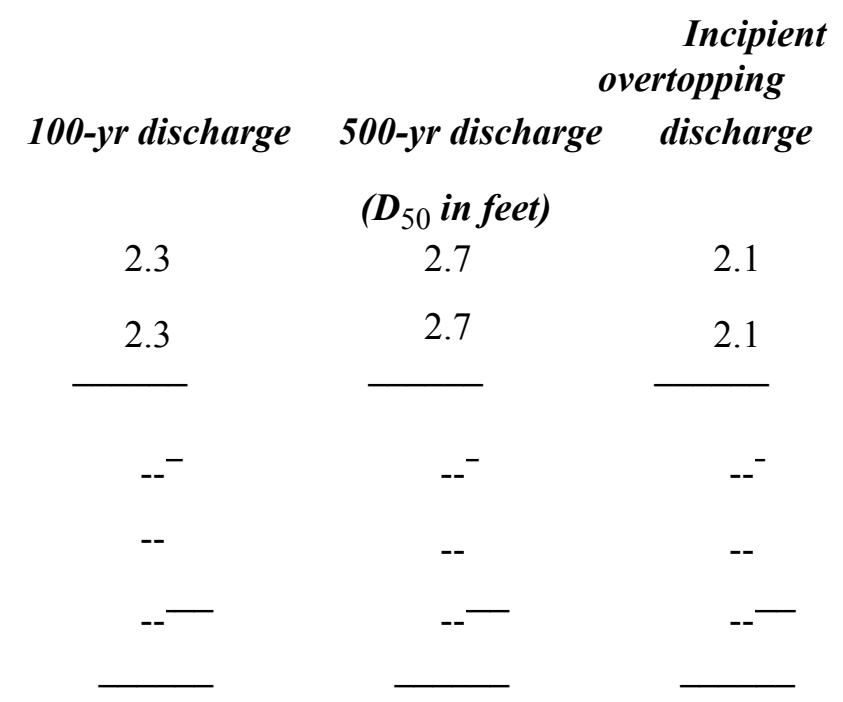




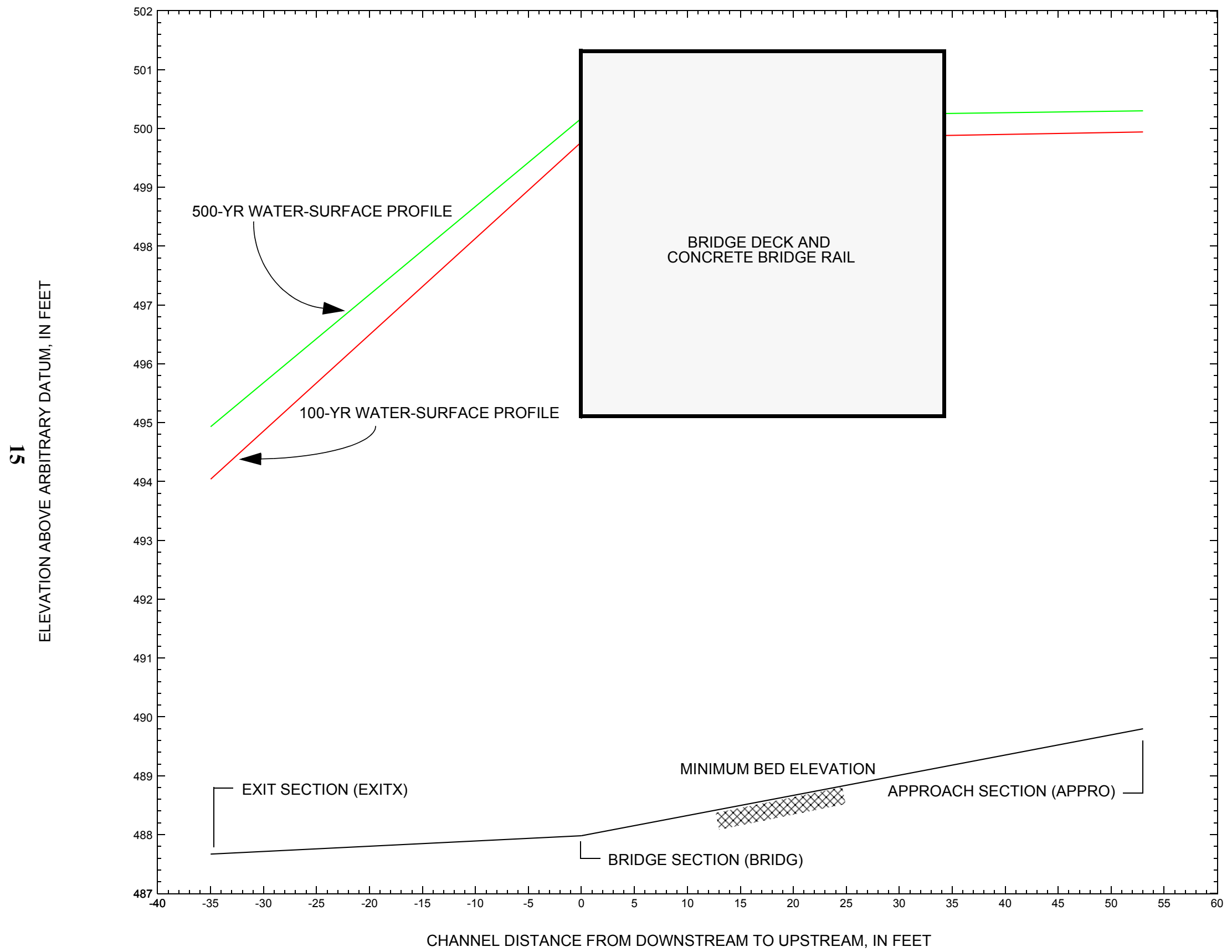

Figure 7. Water-surface profiles for the 100- and 500-yr discharges at structure NEWFTH00010008 on Town Highway 1, crossing Wardsboro Brook, Newfane, Vermont. 


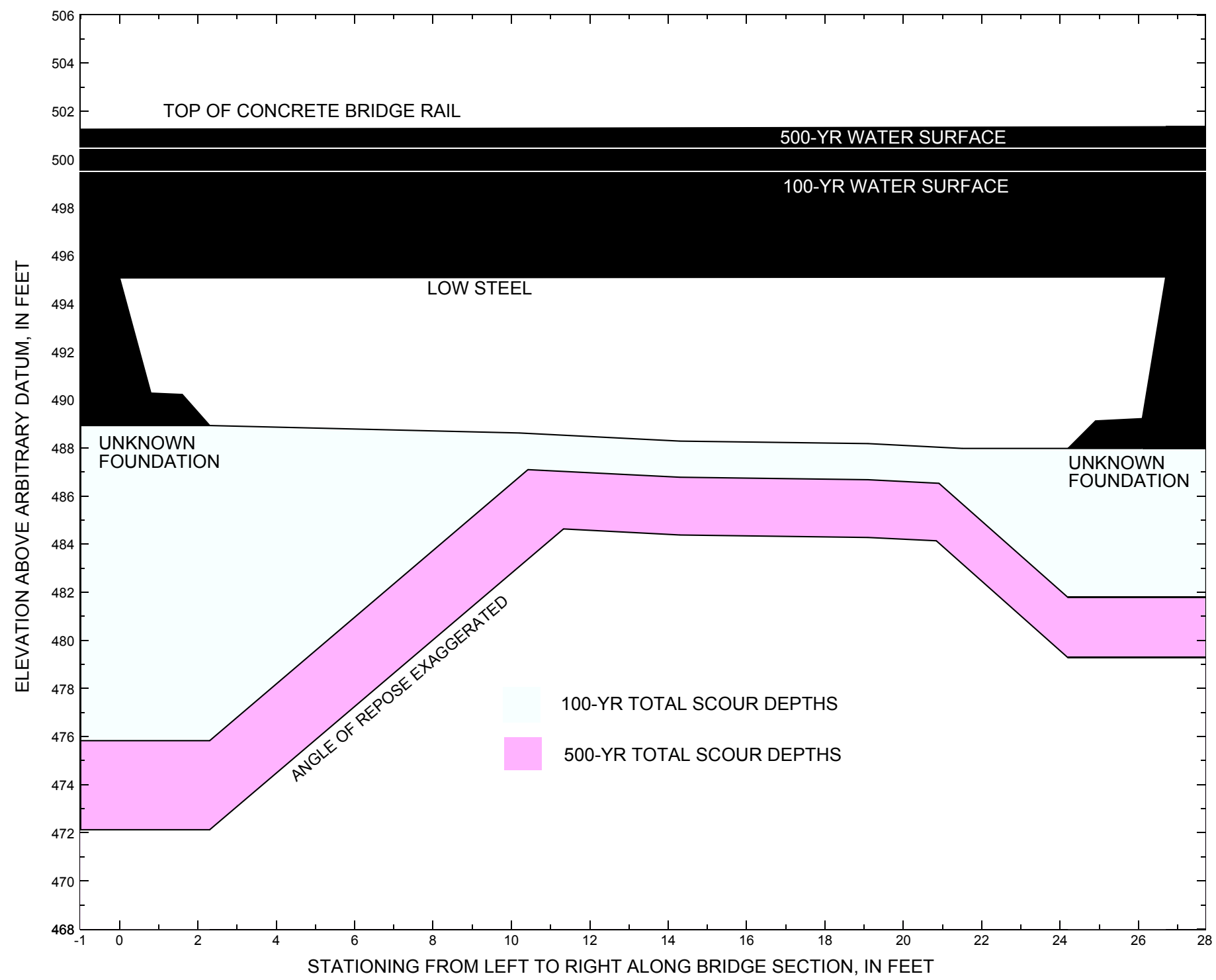

Figure 8. Scour elevations for the 100- and 500-yr discharges at structure NEWFTH00010008 on Town Highway 1, crossing Wardsboro Brook, Newfane, Vermont. 
Table 1. Remaining footing/pile depth at abutments for the 100-yr discharge at structure NEWFTH00010008 on Town Highway 1, crossing Wardsboro Brook, Newfane, Vermont.

[VTAOT, Vermont Agency of Transportation; --, no data]

\begin{tabular}{|c|c|c|c|c|c|c|c|c|c|c|c|}
\hline Description & Station $^{1}$ & $\begin{array}{l}\text { VTAOT } \\
\text { minimum } \\
\text { low-chord } \\
\text { elevation } \\
\text { (feet) }\end{array}$ & $\begin{array}{l}\text { Surveyed } \\
\text { minimum } \\
\text { low-chord } \\
\text { elevation } \\
\quad \text { (feet) }\end{array}$ & $\begin{array}{c}\text { Bottom of } \\
\text { footing/pile } \\
\text { elevation }{ }^{2} \\
\text { (feet) }\end{array}$ & $\begin{array}{c}\text { Channel } \\
\text { elevation at } \\
\text { abutment/ } \\
\text { pier }^{2} \\
\text { (feet) }\end{array}$ & $\begin{array}{l}\text { Contraction } \\
\text { scour depth } \\
\text { (feet) }\end{array}$ & $\begin{array}{l}\text { Abutment } \\
\text { scour } \\
\text { depth } \\
\text { (feet) }\end{array}$ & $\begin{array}{l}\text { Pier } \\
\text { scour } \\
\text { depth } \\
\text { (feet) }\end{array}$ & $\begin{array}{l}\text { Depth of } \\
\text { total scour } \\
\text { (feet) }\end{array}$ & $\begin{array}{c}\text { Elevation of } \\
\text { scour }^{2} \\
\text { (feet) }\end{array}$ & $\begin{array}{c}\text { Remaining } \\
\text { footing/pile } \\
\text { depth } \\
\text { (feet) }\end{array}$ \\
\hline \multicolumn{12}{|c|}{100 -yr discharge is 1,690 cubic-feet per second } \\
\hline Left abutment & 0.0 & -- & 495.1 & -- & 488.9 & 1.5 & 11.6 & -- & 13.1 & 475.8 & -- \\
\hline Right abutment & 26.7 & -- & 495.1 & -- & 488.0 & 1.5 & 4.7 & -- & 6.2 & 481.8 & -- \\
\hline
\end{tabular}

1.Measured along the face of the most constricting side of the bridge.

2.Arbitrary datum for this study.

Table 2. Remaining footing/pile depth at abutments for the 500-yr discharge at structure NEWFTH00010008 on Town Highway 1, crossing Wardsboro Brook, Newfane, Vermont.

[VTAOT, Vermont Agency of Transportation; --, no data]

\begin{tabular}{|c|c|c|c|c|c|c|c|c|c|c|c|}
\hline Description & Station $^{1}$ & $\begin{array}{l}\text { VTAOT } \\
\text { minimum } \\
\text { low-chord } \\
\text { elevation } \\
\text { (feet) }\end{array}$ & $\begin{array}{c}\text { Surveyed } \\
\text { minimum } \\
\text { low-chord } \\
\text { elevation } \\
\text { (feet) }\end{array}$ & $\begin{array}{c}\text { Bottom of } \\
\text { footing/pile } \\
\text { elevation } \\
\text { (feet) }\end{array}$ & $\begin{array}{c}\text { Channel } \\
\text { elevation at } \\
\text { abutment/ } \\
\text { pier }^{2} \\
\text { (feet) }\end{array}$ & $\begin{array}{l}\text { Contraction } \\
\text { scour depth } \\
\text { (feet) }\end{array}$ & $\begin{array}{c}\text { Abutment } \\
\text { scour } \\
\text { depth } \\
\text { (feet) }\end{array}$ & $\begin{array}{l}\text { Pier } \\
\text { scour } \\
\text { depth } \\
\text { (feet) }\end{array}$ & $\begin{array}{l}\text { Depth of } \\
\text { total scour } \\
\text { (feet) }\end{array}$ & $\begin{array}{c}\text { Elevation of } \\
\text { scour }^{2} \\
\text { (feet) }\end{array}$ & $\begin{array}{c}\text { Remaining } \\
\text { footing/pile } \\
\text { depth } \\
\text { (feet) }\end{array}$ \\
\hline \multicolumn{12}{|c|}{500 -yr discharge is 2,350 cubic-feet per second } \\
\hline Left abutment & 0.0 & -- & 495.1 & -- & 488.9 & 3.9 & 12.9 & -- & 16.8 & 472.1 & -- \\
\hline Right abutment & 26.7 & -- & 495.1 & -- & 488.0 & 3.9 & 4.8 & -- & 8.7 & 479.3 & -- \\
\hline
\end{tabular}

1.Measured along the face of the most constricting side of the bridge.

2.Arbitrary datum for this study. 


\section{SELECTED REFERENCES}

Arcement, G.J., Jr., and Schneider, V.R., 1989, Guide for selecting Manning's roughness coefficients for natural channels and flood plains: U.S. Geological Survey Water-Supply Paper 2339, 38 p.

Barnes, H.H., Jr., 1967, Roughness characteristics of natural channels: U.S. Geological Survey Water-Supply Paper 1849,213 p.

Benson, M. A., 1962, Factors Influencing the Occurrence of Floods in a Humid Region of Diverse Terrain: U.S. Geological Survey WaterSupply Paper 1580-B, 64 p.

Brown, S.A. and Clyde, E.S., 1989, Design of riprap revetment: Federal Highway Administration Hydraulic Engineering Circular No. 11, Publication FHWA-IP-89-016, 156 p.

Federal Highway Administration, 1983, Runoff estimates for small watersheds and development of sound design: Federal Highway Administration Report FHWA-RD-77-158.

Federal Highway Administration, 1993, Stream Stability and Scour at Highway Bridges: Participant Workbook: Federal Highway Administration Report FHWA-HI-91-011.

Froehlich, D.C., 1989, Local scour at bridge abutments in Ports, M.A., ed., Hydraulic Engineering--Proceedings of the 1989 National Conference on Hydraulic Engineering: New York, American Society of Civil Engineers, p. 13-18.

Hayes, D.C.,1993, Site selection and collection of bridge-scour data in Delaware, Maryland, and Virginia: U.S. Geological Survey WaterResources Investigation Report 93-4017, 23 p.

Interagency Advisory Committee on Water Data, 1982, Guidelines for determining flood flow frequency: U.S. Geological Survey, Bulletin 17B of the Hydrology Subcommittee, 190 p.

Johnson, C.G. and Tasker, G.D.,1974, Progress report on flood magnitude and frequency of Vermont streams: U.S. Geological Survey OpenFile Report 74-130, 37 p.

Lagasse, P.F., Schall, J.D., Johnson, F., Richardson, E.V., Chang, F., 1995, Stream Stability at Highway Structures: Federal Highway Administration Hydraulic Engineering Circular No. 20, Publication FHWA-IP-90-014, 144 p.

Laursen, E.M., 1960, Scour at bridge crossings: Journal of the Hydraulics Division, American Society of Civil Engineers, v. 86, no. HY2, p. 39-53.

Potter, W. D., 1957a, Peak rates of runoff in the Adirondack, White Mountains, and Maine woods area, Bureau of Public Roads

Potter, W. D., 1957b, Peak rates of runoff in the New England Hill and Lowland area, Bureau of Public Roads

Richardson, E.V. and Davis, S.R., 1995, Evaluating scour at bridges: Federal Highway Administration Hydraulic Engineering Circular No. 18, Publication FHWA-IP-90-017, 204 p.

Richardson, E.V., Simons, D.B., and Julien, P.Y., 1990, Highways in the river environment: Federal Highway Administration Publication FHWA-HI-90-016.

Ritter, D.F., 1984, Process Geomorphology: W.C. Brown Co., Debuque, Iowa, 603 p.

Shearman, J.O., 1990, User's manual for WSPRO--a computer model for water surface profile computations: Federal Highway Administration Publication FHWA-IP-89-027, 187 p.

Shearman, J.O., Kirby, W.H., Schneider, V.R., and Flippo, H.N., 1986, Bridge waterways analysis model; research report: Federal Highway Administration Publication FHWA-RD-86-108, 112 p.

Talbot, A.N., 1887, The determination of water-way for bridges and culverts.

U.S. Geological Survey, 1984a, Newfane, Vermont 7.5 by 15 Minute Series quadrangle map: U.S. Geological Survey Topographic Maps, Scale 1:25,000.

U.S. Geological Survey, 1984b, Townshend, Vermont 7.5 by 15 Minute Series quadrangle map: U.S. Geological Survey Topographic Maps, Scale 1:25,000. 


\section{APPENDIX A: \\ WSPRO INPUT FILE}




\section{WSPRO INPUT FILE}

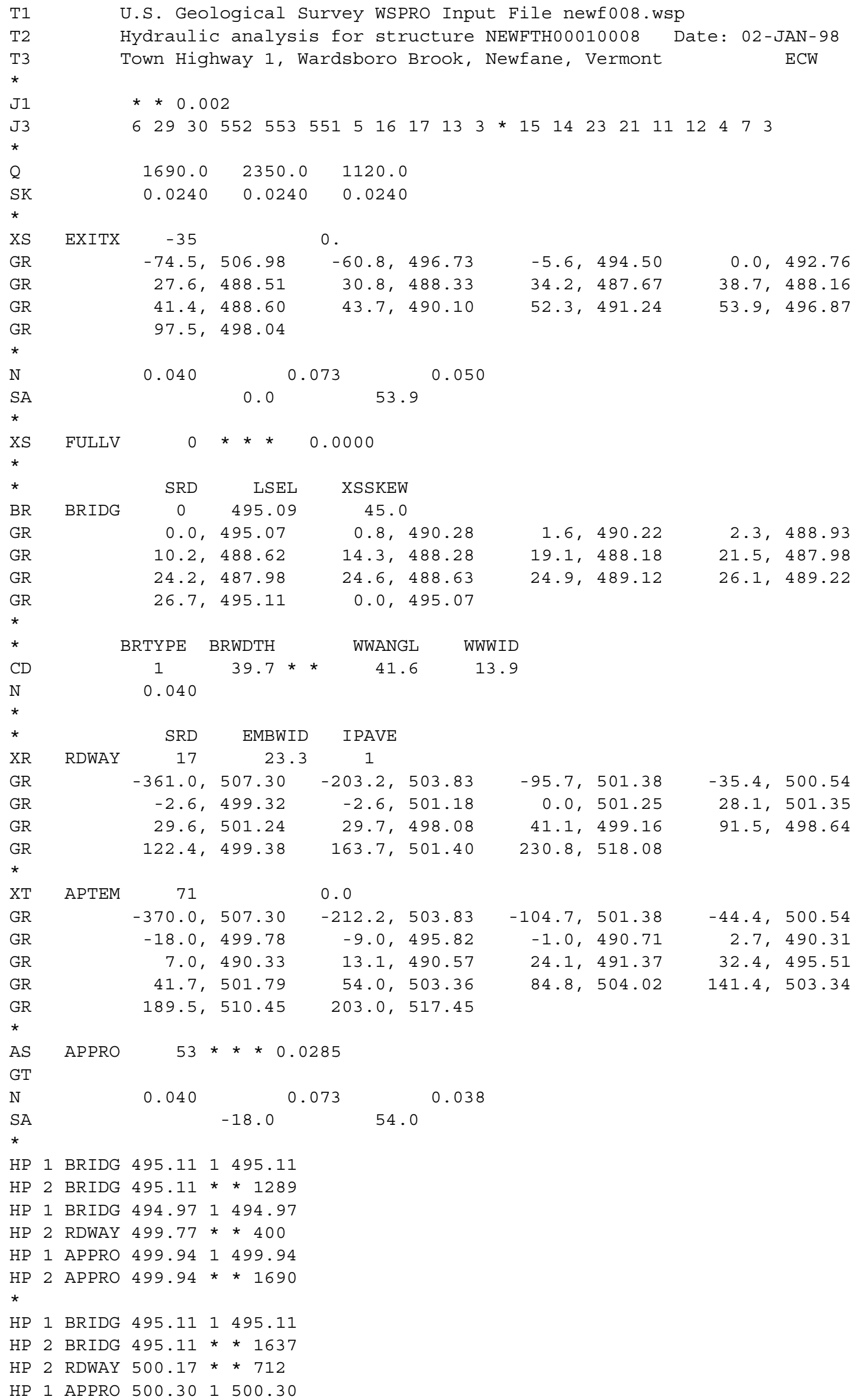




\section{APPENDIX B: \\ WSPRO OUTPUT FILE}




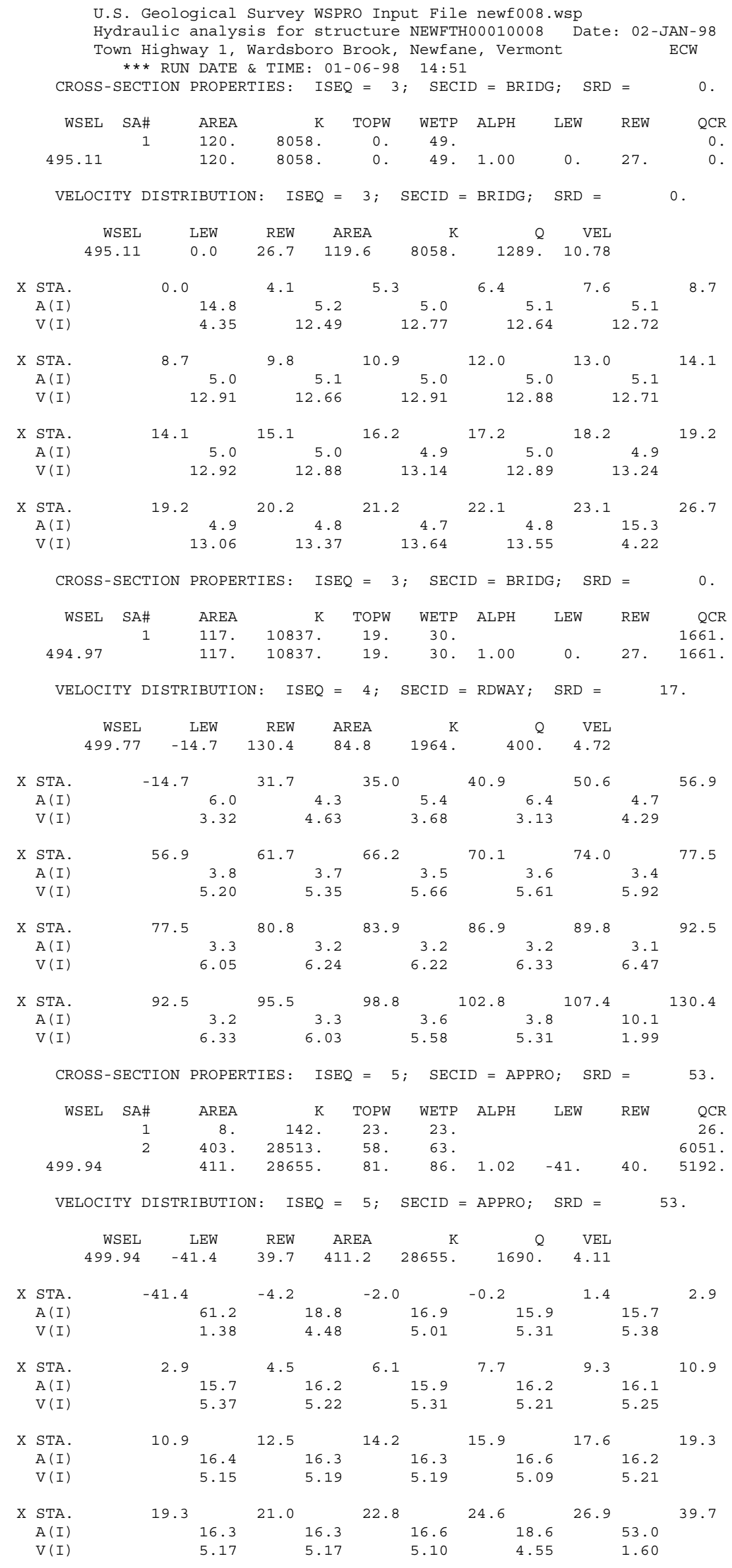


WSPRO OUTPUT FILE (continued)

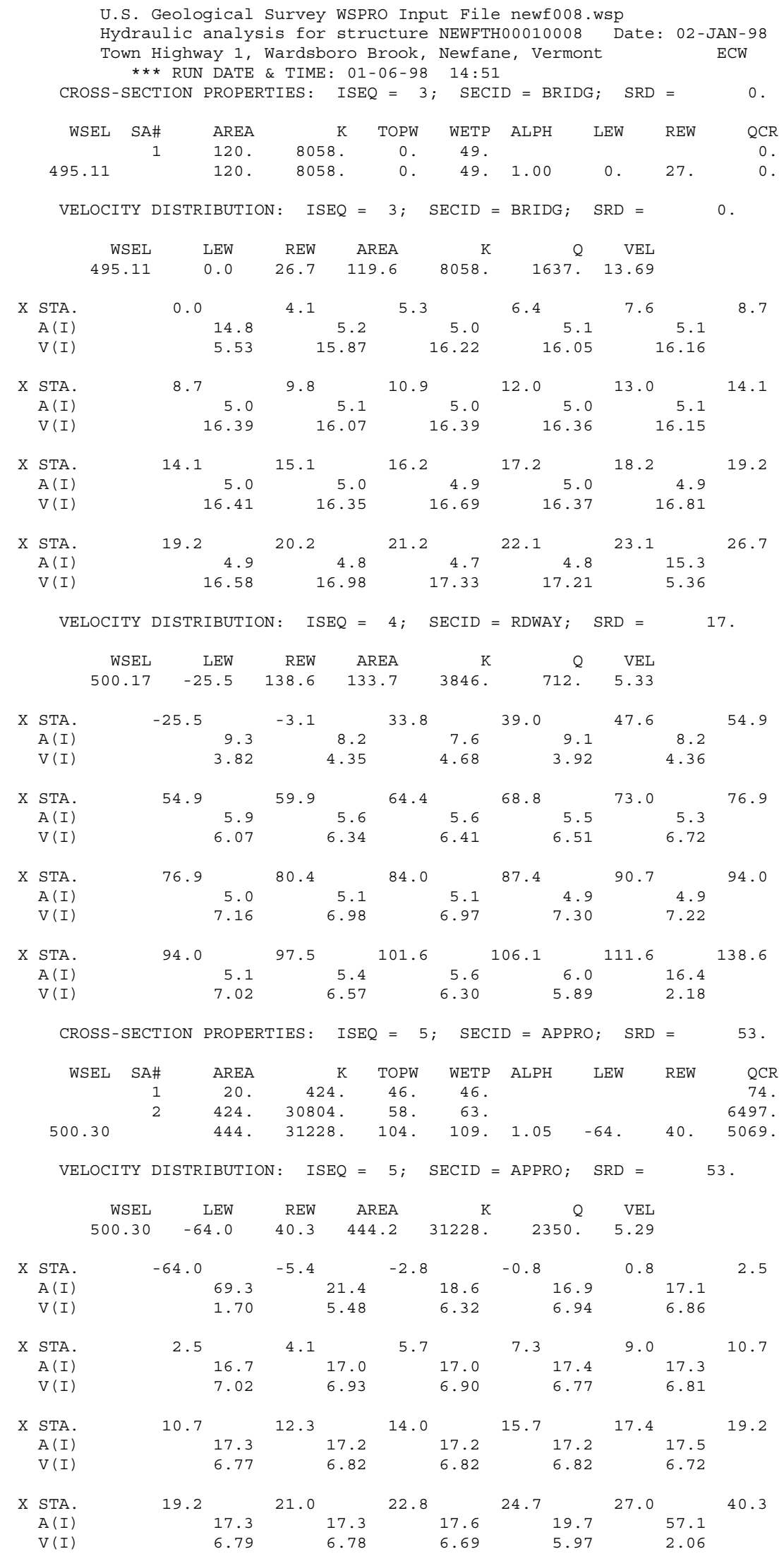


WSPRO OUTPUT FILE (continued)

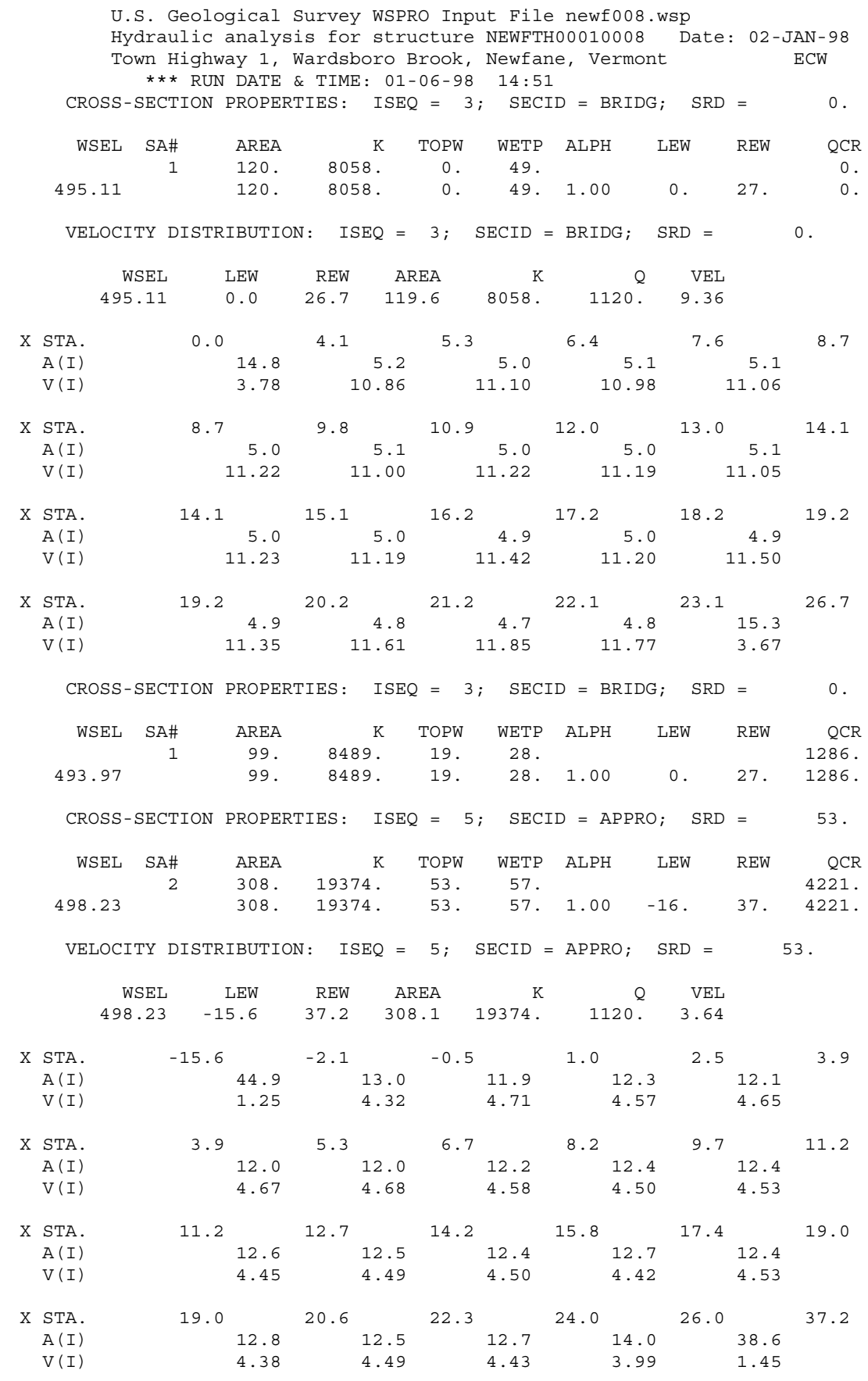


WSPRO OUTPUT FILE (continued)

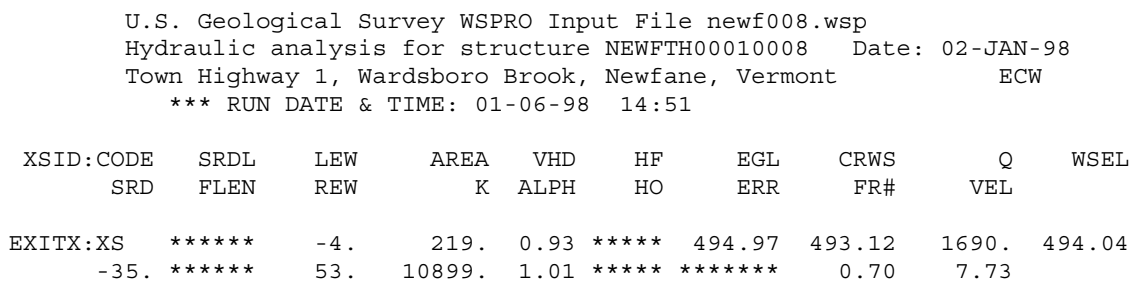

$===135$ CONVEYANCE RATIO OUTSIDE OF RECOMMENDED LIMITS

"FULLV" KRATIO $=1.41$

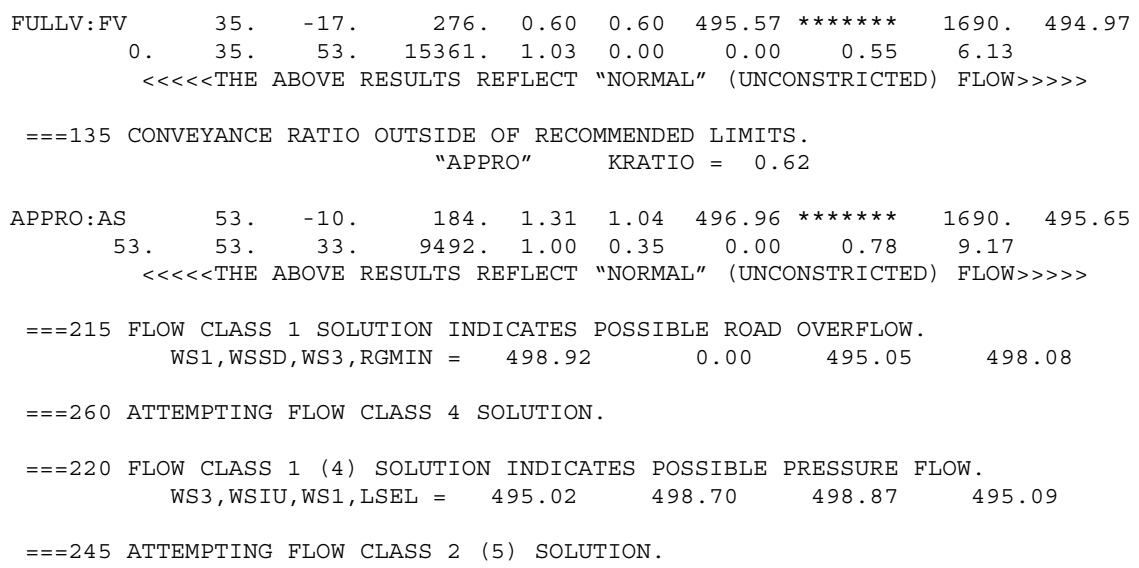


WSPRO OUTPUT FILE (continued)

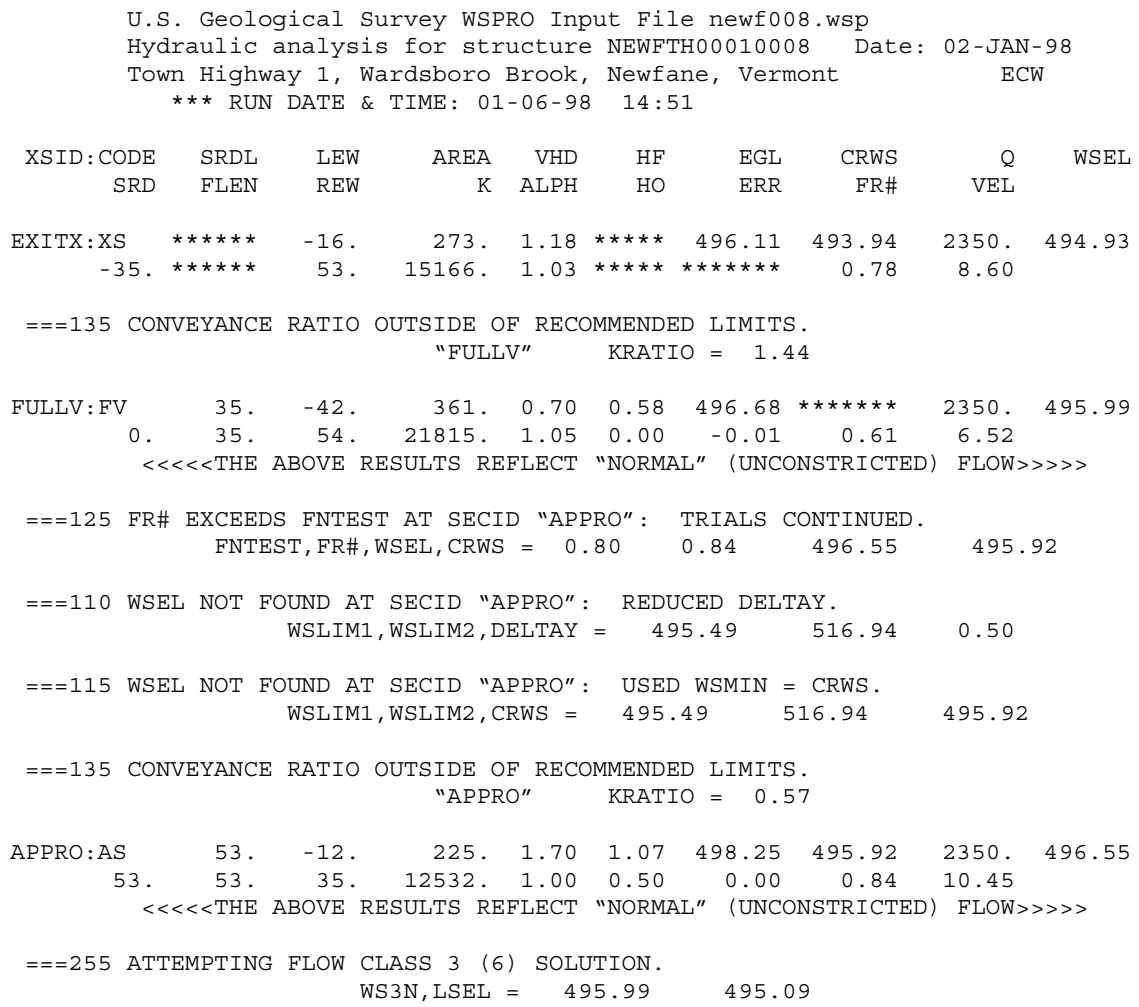


WSPRO OUTPUT FILE (continued)

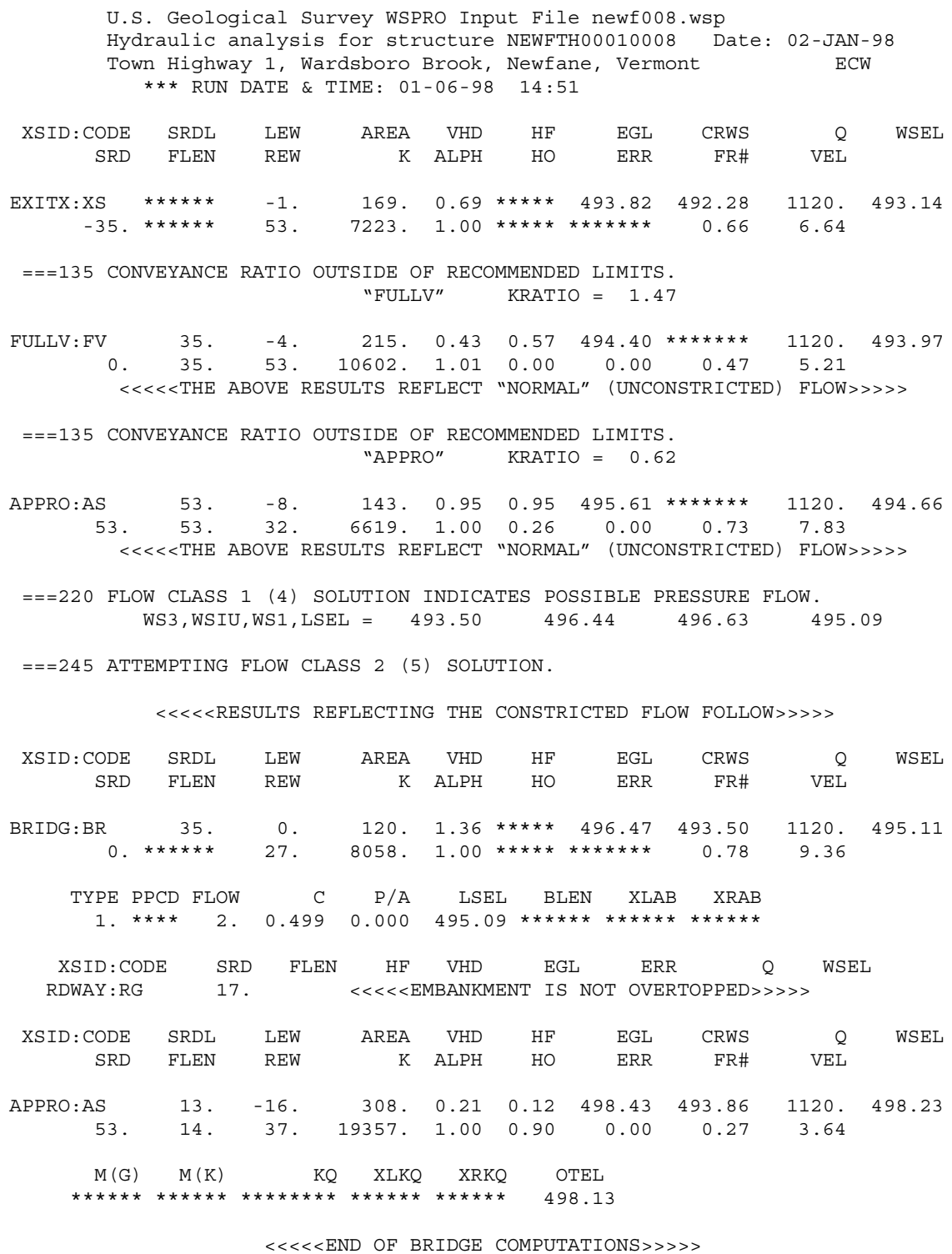

FIRST USER DEFINED TABLE.

\begin{tabular}{|c|c|c|c|c|c|c|c|c|}
\hline XSID : CODE & SRD & LEW & REW & Q & $\mathrm{K}$ & AREA & VEL & WSEL \\
\hline EXITX:XS & -35 & -1 & 53. & 1120. & 7223 & 169. & 6.64 & 493.14 \\
\hline FULLV : FV & 0. & -4 . & 53. & 1120. & 10602 . & 215 . & 5.21 & 493.97 \\
\hline BRIDG : BR & 0 . & 0 . & 27. & 1120. & 8058 & 120. & 9.36 & 495.11 \\
\hline RDWAY : RG & 17. & $* * * * *$ & $* \star \star \star$ & 0 & 0 & 0 & 1.00 & 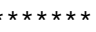 \\
\hline APPRO:AS & 53. & -16 & 37. & 1120. & 19357. & 308 . & 3.64 & 498.23 \\
\hline XSID : CODE & XLKQ & XRKQ & & & & & & \\
\hline
\end{tabular}

SECOND USER DEFINED TABLE.

$\begin{array}{lcrrrrrrrr}\text { XSID : CODE } & \text { CRWS } & \text { FR\# } & \text { YMIN } & \text { YMAX } & \text { HF } & \text { HO } & \text { VHD } & \text { EGL } & \text { WSEL } \\ \text { EXITX:XS } & 492.28 & 0.66 & 487.67 & 506.98 * * * * * * * * * * & 0.69 & 493.82 & 493.14 \\ \text { FULLV:FV } & * * * * * * * * & 0.47 & 487.67 & 506.98 & 0.57 & 0.00 & 0.43 & 494.40 & 493.97 \\ \text { BRIDG :BR } & 493.50 & 0.78 & 487.98 & 495.11 * * * * * * * * * * & 1.36 & 496.47 & 495.11 \\ \text { RDWAY : RG } & * * * * * * * * * * * * * * * * & 498.08 & 518.08 * * * * * * * * * * * & 0.21 & 498.33 * * * * * * * * \\ \text { APPRO:AS } & 493.86 & 0.27 & 489.80 & 516.94 & 0.12 & 0.90 & 0.21 & 498.43 & 498.23 \\ \text { ER } & & & & & & & & \end{array}$

NORMAL END OF WSPRO EXECUTION. 


\section{APPENDIX C:}

\section{BED-MATERIAL PARTICLE-SIZE DISTRIBUTION}




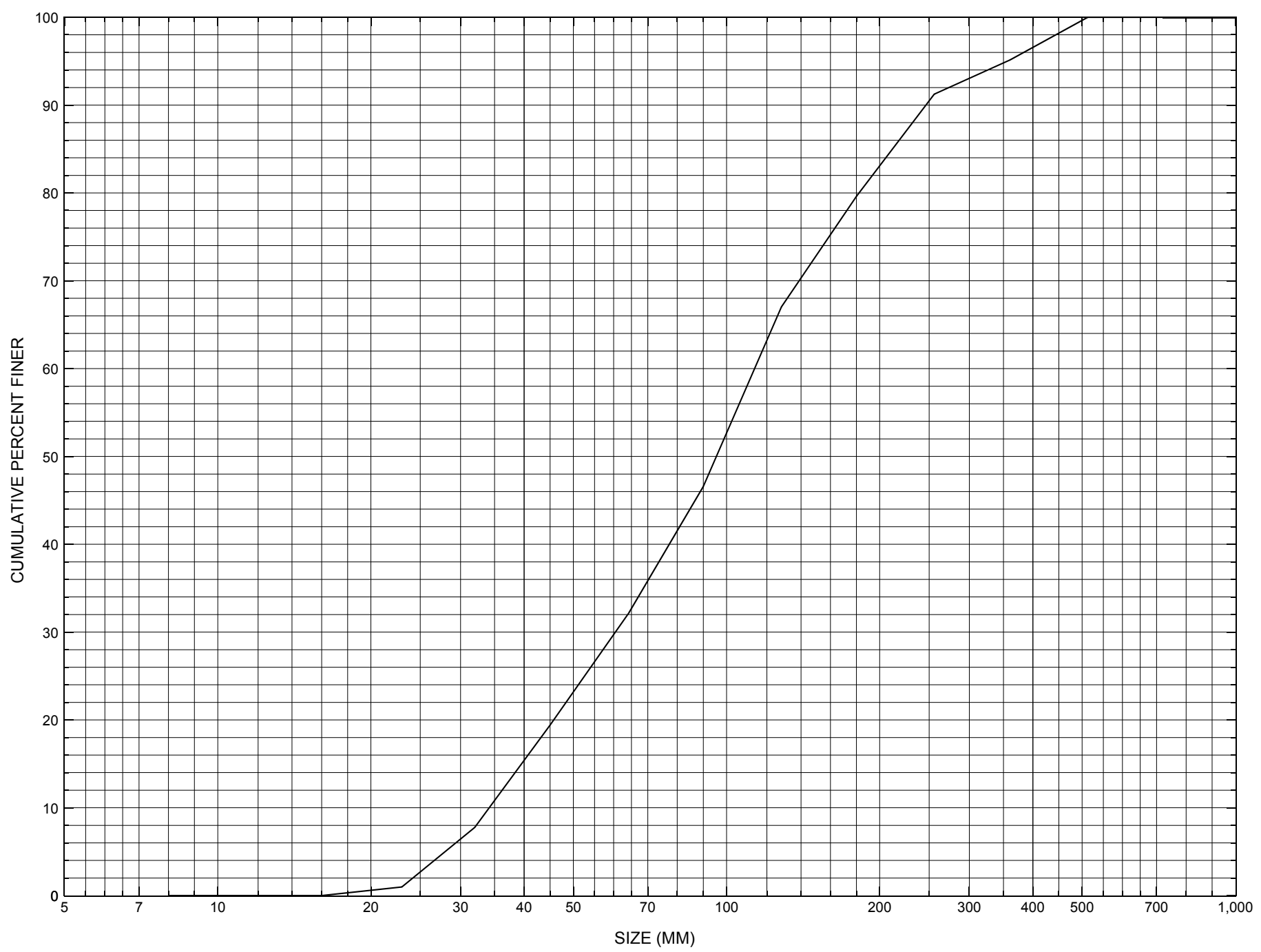

Appendix C. Bed material particle-size distribution for a pebble count in the channel approach of structure NEWFTH00010008, in Newfane, Vermont. 


\section{APPENDIX D: \\ HISTORICAL DATA FORM}




\section{Structure Number NEWFTH00010008}

\section{General Location Descriptive}

Data collected by (First Initial, Full last name) $\underline{\text { M. IVANOFF }}$

Date $(M M / D D / Y Y) \_\mathbf{0 4} / \underline{06} / \underline{95}$

Highway District Number (I - 2; nn) $\mathbf{0 2}$

Town (FIPS place code; I - 4; nnnnn) $\mathbf{4 8 4 0 0}$

Waterway (I - 6) WARDSBORO BROOK

Route Number TH001

Topographic Map Newfane

Latitude (I - 16; nnnn.n) $\mathbf{4 2 5 9 8}$
County (FIPS county code; I - 3; nnn)

Mile marker (I - 11; nnn.nnn) $\mathbf{0 0 0 0 0 0}$

Road Name (I - 7): -

Vicinity (I - 9) 0.15 MI TO JCT W C3 TH12

Hydrologic Unit Code: $\mathbf{0 1 0 8 0 1 0 7}$

Longitude (i - 17; nnnnn.n) $\mathbf{7 2 4 0 8}$

\section{Select Federal Inventory Codes}

FHWA Structure Number (I - 8) 10131200081312

Maintenance responsibility $(I-21 ; n n) \quad \mathbf{0 3}$

Year built (I - 27; YYYY) 1926

Average daily traffic, ADT (I - 29; nnnnnn) 000540

Year of ADT (I - 30; YY) $\mathbf{9 1}$

Opening skew to Roadway $(I-34 ; n n) \quad 15$

Operational status $(I-41 ; X)$ A

Structure type (I - 43; nnn) 104

Approach span structure type (I - 44; nnn) $\mathbf{0 0 0}$

Number of spans (I - 45; nnn) $\underline{\mathbf{0 0 1}}$

Number of approach spans (I - 46; nnnn) $\mathbf{0 0 0 0}$

Comments:

The structural inspection report of $07 / 26 / 94$ indicates the structure is a concrete T-beam type bridge with an asphalt road surface. Both abutments have newer concrete subfootings along them. The waterway consists of stone and gravel, with some random boulders. Across the channel, along the upstream bridge face, there is a home-made stone and plastic dam roughly 2 feet high. There are a few minor voids beneath the subfooting of the right abutment near the upstream end. The downstream right wingwall has some concrete patching along the front face. Stone fill protection consists of some small stone along with a few large boulders.
Maximum span length (I - 48; nnnn) $\underline{\mathbf{0 0 2 6}}$

Structure length (I - 49; nnnnnn) $\underline{\mathbf{0 0 0 0 3 2}}$

Deck Width (I - 52; nn.n) 233

Channel \& Protection $(I-61 ; n) \underline{5}$

Waterway adequacy $(I-71 ; n) \underline{6}$

Underwater Inspection Frequency $(I-92 B ; X Y Y) \_$N

Year Reconstructed (I - 106) $\mathbf{0 0 0 0}$

Clear span (nnn.n ft) _

Vertical clearance from streambed (nnn.n ft) $\underline{\mathbf{0 0 6 . 0}}$

Waterway of full opening $\left(n n n . n \mathrm{ft}^{2}\right)$ 


\section{Bridge Hydrologic Data}

Is there hydrologic data available? $\underline{\mathbf{N}}$ if No, type ctrl-n $h \quad$ VTAOT Drainage area $\left(m i^{2}\right)$ : -

Terrain character:

Stream character \& type: -

Streambed material:

Discharge Data (cfs):

$$
\begin{aligned}
& Q_{2.33}- \\
& Q_{50}-
\end{aligned}
$$

Record flood date $(M M / D D / Y Y)$ :

Estimated Discharge (cfs): Ice conditions (Heavy, Moderate, Light) : -

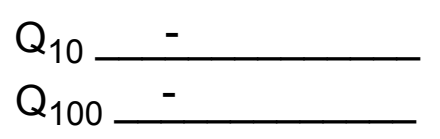

$$
\begin{aligned}
& Q_{25}- \\
& Q_{500}-
\end{aligned}
$$

Water surface elevation $(f t):-$

The stage increases to maximum highwater elevation (Rapidly, Not rapidly):

The stream response is (Flashy, Not flashy):

Describe any significant site conditions upstream or downstream that may influence the stream's stage: -

Watershed storage area (in percent): _ _ \%

The watershed storage area is: - (1-mainly at the headwaters; 2- uniformly distributed; 3-immediatly upstream oi the site)

Water Surface Elevation Estimates for Existing Structure:

\begin{tabular}{|l|l|l|l|l|l|}
\hline Peak discharge frequency & $Q_{2.33}$ & $Q_{10}$ & $Q_{25}$ & $Q_{50}$ & $Q_{100}$ \\
Water surface elevation (ft)) & - & - & - & - & - \\
Velocity (ft/sec) & - & - & - & - & - \\
\hline
\end{tabular}

Long term stream bed changes: -

Is the roadway overtopped below the $\mathrm{Q}_{100}$ ? (Yes, No, Unknown): $\mathbf{U}$ Frequency: Relief Elevation (ft): Discharge over roadway at $Q_{100}\left(f^{3} / \mathrm{sec}\right)$ :

Are there other structures nearby? (Yes, No, Unknown): $\underline{\mathbf{U}}$ Upstream distance (miles): Town: If No or Unknown, type ctrl-n os Highway No. : Structure No. : Year Built:

Clear span (ft): Clear Height $(f t)$ : Full Waterway $\left(f^{2}\right)$ : 
Downstream distance (miles): Town: Year Built:

Highway No. : Structure No. : Structure Type:

Clear span (ft): Clear Height $(f t)$ : Full Waterway $\left(f^{2}\right)$ : -

Comments:

\section{USGS Watershed Data}

Watershed Hydrographic Data

Drainage area $(D A)$

Watershed storage (ST) $\mathrm{mi}^{2}$ Lake/pond/swamp area 0.10 $\mathrm{mi}^{2}$

Bridge site elevation 886 $\mathrm{ft}$ $\%$

Main channel length 5.64 mi $10 \%$ channel length elevation 1319 $\mathrm{ft} \quad 85 \%$ channel length elevation 1575 $\mathrm{ft}$

Main channel slope $(S)$

(S) 60.52 $\mathrm{ft} / \mathrm{mi}$

Watershed Precipitation Data

Average site precipitation in Average headwater precipitation in

Maximum 2yr-24hr precipitation event $(124,2)$ in

Average seasonal snowfall (Sn) $\mathrm{ft}$ 


\section{Bridge Plan Data}

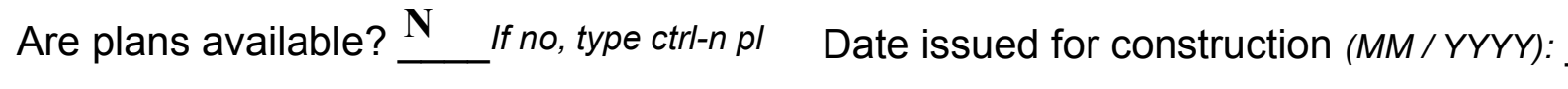

Project Number

Minimum channel bed elevation:

Low superstructure elevation: USLAB DSLAB USRAB DSRAB Benchmark location description:

NO BENCHMARK INFORMATION

Reference Point (MSL, Arbitrary, Other): Datum (NAD27, NAD83, Other):

Foundation Type: 4

If 1: Footing Thickness

If 2: Pile Type: (1-Wood; 2-Ster

(1-

(1-Spreadfooting; 2-Pile; 3- Gravity; 4-Unknown)

Footing bottom elevation:

If 3: Footing bottom elevation:

Foundation Material Type: 3

Briefly describe material at foundation bottom elevation or around piles:

NO FOUNDATION MATERIAL INFORMATION 


\section{Cross-sectional Data}

Is cross-sectional data available? Yes If no, type ctrl-n xs

Source (FEMA, VTAOT, Other)? VTAOT

The stations and elevations are in feet. The elevation coordinate has been made to match the Comments: coordinate system set up in this report, using the low chord point as a line-up.

\begin{tabular}{|l|l|l|l|l|l|l|l|l|l|l|l|}
\hline Station & $\mathbf{0}$ & $\mathbf{1 . 1 7}$ & $\mathbf{1 . 1 8}$ & $\mathbf{1 3}$ & $\mathbf{2 4 . 8 3}$ & $\mathbf{2 4 . 8 4}$ & $\mathbf{2 6}$ & - & - & - & - \\
\hline Feature & LAB & - & - & - & - & - & - & - & - & - & - \\
\hline $\begin{array}{l}\text { Low chord } \\
\text { elevation }\end{array}$ & 495.1 & 495.1 & 495.1 & 495.1 & 495.1 & 495.1 & 495.1 & - & - & - & - \\
\hline $\begin{array}{l}\text { Bed } \\
\text { elevation }\end{array}$ & 490.2 & 490.2 & 489.1 & 488.8 & 488.1 & 489.9 & 489.9 & - & - & - & - \\
\hline $\begin{array}{l}\text { Low chord } \\
\text { to bed }\end{array}$ & 4.9 & 4.9 & 6 & 6.3 & 7 & 5.2 & 5.2 & - & - & - & - \\
\hline Station & - & - & - & - & - & - & - & - & - & - & - \\
\hline Feature & - & - & - & - & - & - & - & - & - & - & - \\
\hline $\begin{array}{l}\text { Low chord } \\
\text { elevation }\end{array}$ & - & - & - & - & - & - & - & - & - & - & - \\
\hline $\begin{array}{l}\text { Bed } \\
\text { elevation }\end{array}$ & - & - & - & - & - & - & - & - & - & - & - \\
\hline $\begin{array}{l}\text { Low chord } \\
\text { to bed }\end{array}$ & - & - & - & - & - & - & - & - & - & - & - \\
\hline
\end{tabular}

Source (FEMA, VTAOT, Other)?

Comments: -

\begin{tabular}{|l|l|l|l|l|l|l|l|l|l|l|l|}
\hline Station & - & - & - & - & - & - & - & - & - & - & - \\
\hline Feature & - & - & - & - & - & - & - & - & - & - & - \\
\hline $\begin{array}{l}\text { Low chord } \\
\text { elevation }\end{array}$ & - & - & - & - & - & - & - & - & - & - & - \\
\hline $\begin{array}{l}\text { Bed } \\
\text { elevation }\end{array}$ & - & - & - & - & - & - & - & - & - & - & - \\
\hline $\begin{array}{l}\text { Low chord } \\
\text { to bed }\end{array}$ & - & - & - & - & - & - & - & - & - & - & - \\
\hline Station & - & - & - & - & - & - & - & - & - & - & - \\
\hline Feature & - & - & - & - & - & - & - & - & - & - & - \\
\hline $\begin{array}{l}\text { Low chord } \\
\text { elevation }\end{array}$ & - & - & - & - & - & - & - & - & - & - & - \\
\hline $\begin{array}{l}\text { Bed } \\
\text { elevation }\end{array}$ & - & - & - & - & - & - & - & - & - & - & - \\
\hline $\begin{array}{l}\text { Low chord } \\
\text { to bed }\end{array}$ & - & - & - & - & - & - & - & - & - & - & - \\
\hline
\end{tabular}




\section{APPENDIX E: \\ LEVEL I DATA FORM}


U. S. Geological Survey

Bridge Field Data Collection and Processing Form

Qa/Qc Check by: MS Date: $6 / 18 / 97$

\section{Structure Number}

NEWFTH00010008

Computerized by: $\mathbf{M S}$

Date: $\underline{6} / \mathbf{2 3} / 97$

Reviewd by: $\quad$ EW Date: $\underline{1 / 14 / 98}$

\section{A. General Location Descriptive}

1. Data collected by (First Initial, Full last name) $\mathbf{J}$. DEGNAN

2. Highway District Number $\mathbf{0 2}$

Mile marker $\mathbf{0 0 0 0 0 0}$

County WINDHAM (025)

Waterway (I - 6) WARDSBORO BROOK

Route Number TH001

Town NEWFANE (48400)

Road Name -

Hydrologic Unit Code: $\mathbf{0 1 0 8 0 1 0 7}$

3. Descriptive comments:

This concrete T-beam type bridge is located 0.15 miles from junction with Town Highway 12.

\section{B. Bridge Deck Observations}
4. Surface cover... LBUS 4
RBUS 6
LBDS 6
RBDS 6
Overall 6

(2b us, ds,lb,rb: 1- Urban; 2- Suburban; 3- Row crops; 4- Pasture; 5- Shrub- and brushland; 6- Forest; 7- Wetland)
5. Ambient water surface... US 2
UB 1
DS 2
(1- pool; 2- riffle)

6. Bridge structure type 1 (1- single span; 2- multiple span; 3- single arch; 4- multiple arch; 5-cylindrical culvert; 6- box culvert; or 7- other)
7. Bridge length $\mathbf{3 2}$
(feet)
Span length $\underline{\mathbf{2 6}}$
(feet)
Bridge width 23.3 (feet)

\section{Road approach to bridge:}
8. LB 2 RB 1
( 0 even, 1- lower, 2- higher)
9. $\mathrm{LB}$
RB 1
(1-Paved, 2- Not paved)

10. Embankment slope (run / rise in feet / foot)

US left

US right

\begin{tabular}{|c|c|c|c|}
\hline \multicolumn{2}{|c|}{ Protection } & \multirow{2}{*}{ 13.Erosion } & 14.Severity \\
\hline 11.Type & 12.Cond. & $\mathbf{0}$ & $\mathbf{0}$ \\
\hline $\mathbf{0}$ & - & $\mathbf{0}$ & $\mathbf{0}$ \\
\hline $\mathbf{0}$ & - & $\mathbf{0}$ & $\underline{\mathbf{0}}$ \\
\hline $\mathbf{5}$ & $\mathbf{1}$ & $\underline{\mathbf{1}}$ \\
\hline $\mathbf{5}$ & $\mathbf{1}$ & $\mathbf{0}$ & $\mathbf{0}$ \\
\hline
\end{tabular}

Bank protection types: 0- none; 1- < 12 inches,

2- $<36$ inches; $3-<48$ inches;

4- < 60 inches; 5- wall / artificial levee

Bank protection conditions: 1- good; 2- slumped;

3- eroded; 4- failed

Erosion: 0 - none; 1- channel erosion; 2 -

road wash; 3- both; 4- other

Erosion Severity: 0 - none; 1- slight; 2- moderate; 3- severe

\section{Channel approach to bridge (BF):}

15. Angle of approach: $\mathbf{1 0}$

16. Bridge skew: 45

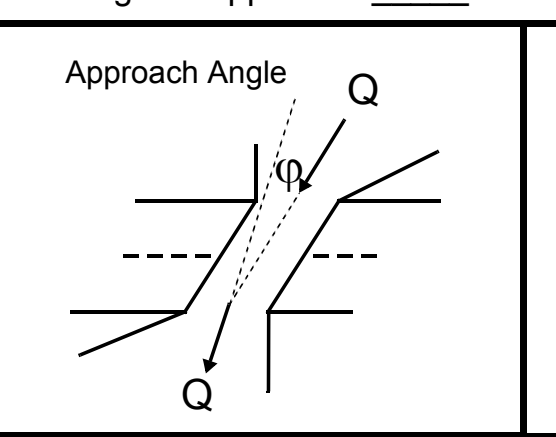

17. Channel impact zone 1 :

Where? LB $(L B, R B)$

Exist? $\underline{\mathbf{y}}(\mathrm{Y}$ or $N)$

Range? 60

feet US

Severity 1

Channel impact zone 2:

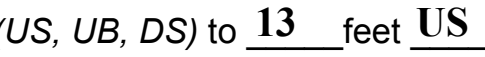

Where? RB (LB, RB)

Exist? $\mathbf{Y}(Y$ or $N)$

Range? feet $\underline{\text { US }}$

Severity 1

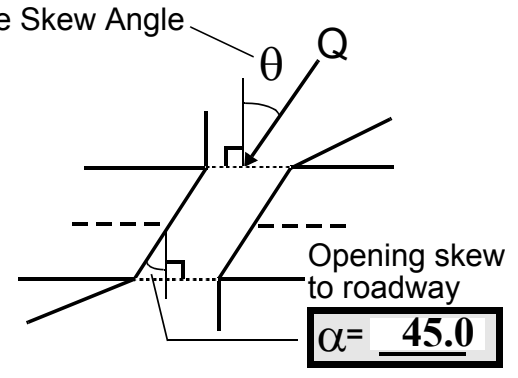

Impact Severity: 0- none to very slight; 1-Slight; 2- Moderate; 3- Severe 
18. Bridge Type: 1a

1a- Vertical abutments with wingwalls

1 b- Vertical abutments without wingwalls

2- Vertical abutments and wingwalls, sloping embankment Wingwalls parallel to abut. face

3- Spill through abutments

4- Sloping embankment, vertical wingwalls and abutments

Wingwall angle less than $90^{\circ}$.

19. Bridge Deck Comments (surface cover variations, measured bridge and span lengths, bridge type variations, approach overflow width, etc.)

4. The US right bank and DS left bank surface cover both include a house and lawn, but the forest is the dominant surface cover.

18. The DS left wingwall is a type 4 wingwall.

\section{Upstream Channel Assessment}

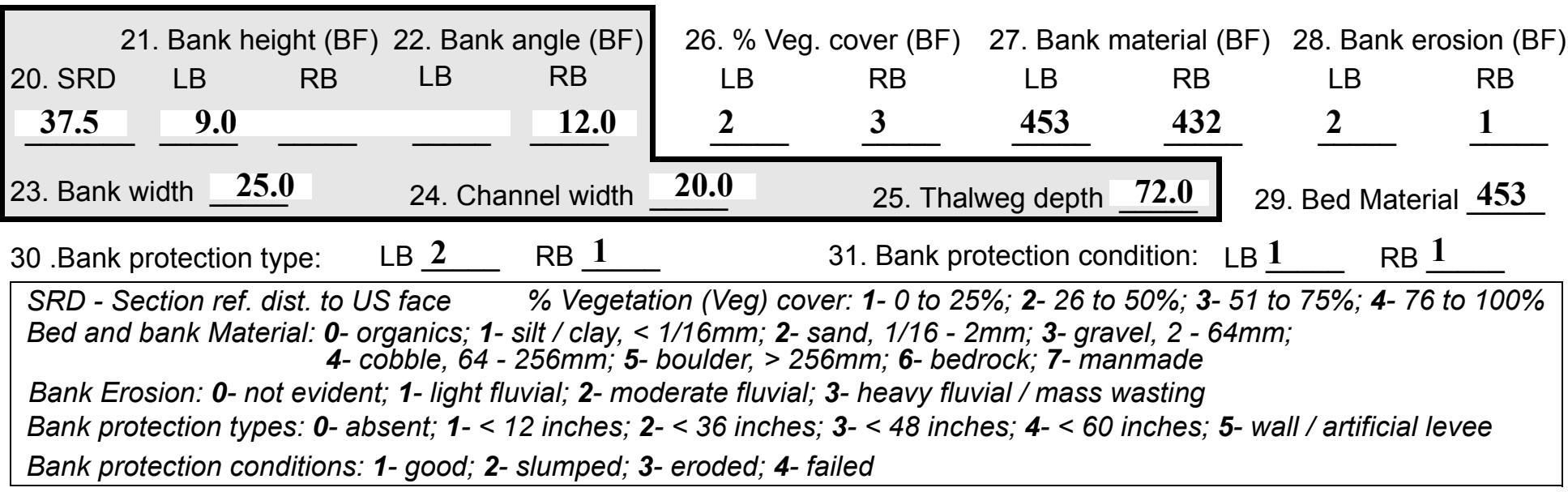

32. Comments (bank material variation, minor inflows, protection extent, etc.):

All measurements are referenced to the mid-point of the bridge face.

The right bank protection extends from $15 \mathrm{ft}$ US to $0 \mathrm{ft}$ US and consists of stone fill.

The left bank protection extends from $40 \mathrm{ft}$ US to $20 \mathrm{ft}$ US and also consists of stone fill. 
36. Point bar extent: $\underline{\mathbf{1 8 0}}$ feet $\underline{\text { US }}$ (US, UB) to $\underline{\mathbf{0}}$ feet $\underline{\mathrm{US}}$ (US, UB, DS) positioned $\underline{\mathbf{6 0}} \%$ LB to $\underline{\mathbf{1 0 0}} \%$ RB

37. Material: 432

38. Point or side bar comments (Circle Point or Side; Note additional bars, material variation, status, etc.):

39. Is a cut-bank present? $\mathbf{Y}$ ( $Y$ or if $N$ type ctrl-n $c b)$

40. Where? $\underline{\mathbf{L B}}$ ( $L B$ or RB)

41. Mid-bank distance: 165

42. Cut bank extent: $\underline{\mathbf{2 3 0}}$ feet $\underline{\mathbf{U S}}$ (US, UB) to $\underline{\mathbf{1 0 0}}$ feet $\underline{\mathbf{U S}}$ (US, UB, DS)

43. Bank damage: 1

(1- eroded and/or creep; 2- slip failure; 3- block failure)

44. Cut bank comments (eg. additional cut banks, protection condition, etc.):

45. Is channel scour present? $\mathbf{N}$ ( $Y$ or if $N$ type ctrl-n cs)

47. Scour dimensions: Length -

Width -

Depth :-

46. Mid-scour distance: -

48. Scour comments (eg. additional scour areas, local scouring process, etc.):

NO CHANNEL SCOUR

49. Are there major confluences? $\mathbf{N}$

51. Confluence 1: Distance -

Confluence 2: Distance -

NO MAJOR CONFLUENCES
( $Y$ or if $N$ type ctrl-n mc)

52. Enters on -

Enters on ( $L B$ or $R B)$ (LB or $R B)$
50. How many? -

53. Type(1- perennial; 2- ephemeral)

Type (1-perennial; 2-ephemeral)

\section{Under Bridge Channel Assessment}

55. Channel restraint (BF)? LB 2

\begin{tabular}{|ccccc}
\hline \multicolumn{2}{|c}{ 56. Height (BF) } & \multicolumn{3}{c}{57 Angle (BF) } \\
LB & RB & LB & RB \\
$\mathbf{2 5 . 0}$ & & & $\mathbf{0 . 5}$ & \\
\hline
\end{tabular}

58. Bank width (BF) (1- natural bank; 2- abutment; 3- artificial levee)

Bed and bank Material: 0- organics; 1- silt / clay, < 1/16mm; 2- sand, 1/16 - 2mm; 3- gravel, 2 - 64mm; 4- cobble, 64 - 256mm; 5- boulder, > 256mm; 6- bedrock; 7- manmade

61. Material (BF) 62. Erosion (BF)

LB RB LB RB

$2 \quad 7 \quad \underline{7} \quad-$

60. Thalweg depth $\mathbf{9 0 . 0}$

63. Bed Material -

Bank Erosion: 0- not evident; 1- light fluvial; 2- moderate fluvial; 3- heavy fluvial / mass wasting

64. Comments (bank material variation, minor inflows, protection extent, etc.):

432 
65. Debris and Ice Is there debris accumulation?

$(Y$ or $N)$ 66. Where? $\underline{Y}$

(1- Upstream; 2- At bridge; 3-Both)

67. Debris Potential 1 ( 1- Low; 2- Moderate; 3- High)

68. Capture Efficiency 3 (1-Low; 2- Moderate; 3- High)

69. Is there evidence of ice build-up? 3 (Y or $N$ )

Ice Blockage Potential $\underline{\mathbf{Y}}$

(1-Low; 2-Moderate; 3- High)

70. Debris and Ice Comments:

3

This bridge constricts the natural channel and is not aligned with flow. The debris potential is high because the vertical clearance between the bridge and stream bed is low. Ice scarring is present along both banks on tree trunks.

\begin{tabular}{|l|c|c|c|c|c|c|c|c|}
\hline Abutments & $\begin{array}{c}\text { 71. Attack } \\
\angle \text { (BF) }\end{array}$ & $\begin{array}{c}\text { 72. Slope } \angle \\
\text { (Qmax) }\end{array}$ & $\begin{array}{c}\text { 73. Toe } \\
\text { loc. (BF) }\end{array}$ & $\begin{array}{c}\text { 74. Scour } \\
\text { Condition }\end{array}$ & $\begin{array}{c}\text { 75. Scour } \\
\text { depth }\end{array}$ & $\begin{array}{c}\text { 76. Exposure } \\
\text { depth }\end{array}$ & 77. Material & 78. Length \\
\hline LABUT & & $\mathbf{0}$ & $\mathbf{8 5}$ & $\mathbf{2}$ & $\mathbf{3}$ & $\mathbf{0}$ & $\mathbf{1}$ & $\mathbf{9 0 . 0}$ \\
\hline RABUT & $\mathbf{1}$ & $\mathbf{5}$ & $\mathbf{8 5}$ & & & $\mathbf{2}$ & $\mathbf{3}$ & $\mathbf{1 9 . 0}$ \\
\hline
\end{tabular}

Pushed: $L B$ or RB

Toe Location (Loc.): 0- even, 1- set back, 2- protrudes

Scour cond.: 0- not evident; 1- evident (comment); 2- footing exposed; 3-undermined footing; 4- piling exposed; 5- settled; 6- failed

Materials: 1- Concrete; 2- Stone masonry or drywall; 3- steel or metal; 4- wood

79. Abutment comments (eg. undermined penetration, unusual scour processes, debris, etc.):

1

2

1

There is a $3 \mathrm{ft}$ of horizontal penetration and a $0.3 \mathrm{ft}$ of vertical penetration along the US end of the left abutment footing. There is also a bar along the left abutment footing. The thalweg runs along the right abutment footing. The right abutment footing has been patched up.

80. Wingwalls: $\begin{array}{lllll} & & & & \\ \text { Exist? } & \text { Material? } & \text { Scour } & \text { Scour } & \text { Exposure } \\ \text { Condition? } & \text { depth? } & \text { depth? }\end{array}$

USLWW:

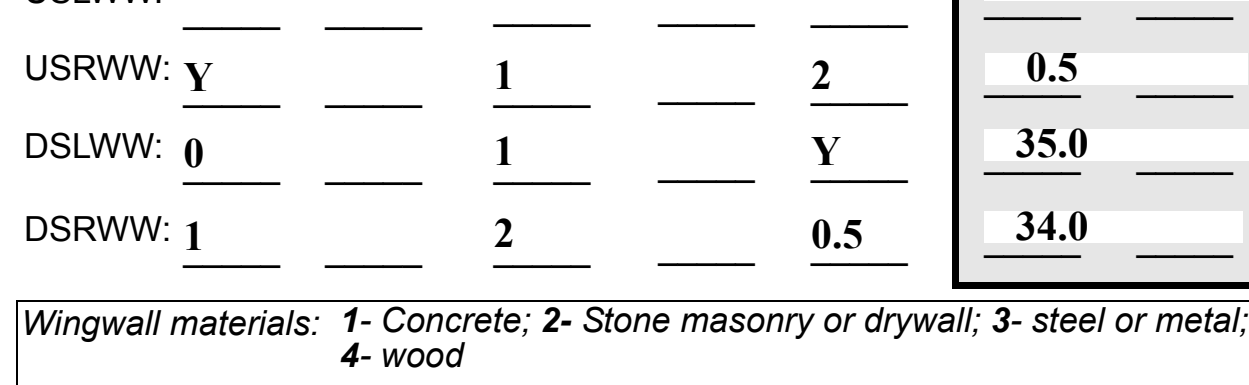

82. Bank / Bridge Protection:

\begin{tabular}{|l|l|l|l|l|l|l|c|c|}
\hline Location & USLWW & USRWW & LABUT & RABUT & LB & RB & DSLWW & DSRWW \\
\hline Type & $\mathbf{2}$ & $\mathbf{2}$ & $\mathbf{Y}$ & $\mathbf{0 . 5}$ & $\mathbf{1}$ & $\mathbf{1}$ & - & - \\
\hline Condition & $\mathbf{Y}$ & $\mathbf{0}$ & $\mathbf{1}$ & $\mathbf{1}$ & $\mathbf{2}$ & $\mathbf{2}$ & - & - \\
\hline Extent & $\mathbf{1}$ & $\mathbf{1}$ & $\mathbf{2}$ & $\mathbf{2}$ & $\mathbf{2}$ & $\mathbf{0}$ & $\mathbf{0}$ & - \\
\hline
\end{tabular}

Bank / Bridge protection types: 0- absent; 1- < 12 inches; 2- < 36 inches; 3- < 48 inches; 4- < 60 inches; 
83. Wingwall and protection comments (eg. undermined penetration, unusual scour processes, etc.):

-
-
-
-
-
0
-
-
0
-
-

\section{Piers:}

84. Are there piers? _ _ (Y or if $N$ type ctrl-n pr)

\begin{tabular}{|l|r|r|r|l|l|l|l|}
\hline \multirow{2}{*}{$\begin{array}{l}85 . \\
\text { Pier no. }\end{array}$} & \multicolumn{3}{|c|}{ width (w) feet } & \multicolumn{3}{c|}{ elevation (e) feet } \\
\cline { 2 - 8 } & w1 & w2 & w3 & e@w1 & e@w2 & e@w3 \\
\hline Pier 1 & $\mathbf{0 . 0}$ & & & $\mathbf{2 6 . 5}$ & $\mathbf{8 0 . 0}$ & $\mathbf{1 0 . 0}$ \\
\hline Pier 2 & & $\mathbf{7 . 0}$ & $\mathbf{9 . 5}$ & $\mathbf{1 3 0 . 0}$ & $\mathbf{1 5 . 0}$ & - \\
\hline Pier 3 & - & - & - & - & - & - \\
\hline Pier 4 & - & - & - & - & - & - \\
-
\end{tabular}

\begin{tabular}{|l|l|l|l|l|}
\hline Level 1 Pier Descr. & 1 & \multicolumn{1}{|c|}{2} & 3 & \multicolumn{1}{|c|}{} \\
\hline 86. Location (BF) & & - & - & - \\
\hline 87. Type & & - & - & - \\
\hline 88. Material & & - & - & - \\
\hline 89. Shape & & - & - & - \\
\hline 90. Inclined? & & - & - & - \\
\hline 91. Attack $\angle$ (BF) & & - & - & - \\
\hline 92. Pushed & & - & - & - \\
\hline 93. Length (feet) & - & - & - & - \\
\hline 94. \# of piles & & - & - & - \\
\hline 95. Cross-members & & - & - & - \\
\hline 96. Scour Condition & & - & - & - \\
\hline 97. Scour depth & $\mathbf{N}$ & - & - & - \\
\hline 98. Exposure depth & - & - & - & - \\
\hline
\end{tabular}

LFP, LTB, LB, MCL, MCM, MCR, RB, RTB, RFP

1- Solid pier, 2- column, 3- bent

1-Wood; 2- concrete; 3- metal; 4- stone

1- Round; 2- Square; 3- Pointed

Y-yes; $N-$ no

$L B$ or $R B$

0- none; 1- laterals; 2- diagonals; 3- both

0- not evident; 1- evident (comment);

2- footing exposed; 3- piling exposed;

4- undermined footing; 5- settled; 6- failed 
99. Pier comments (eg. undermined penetration, protection and protection extent, unusual scour processes, etc.):

-
-
-
-
-
-
-
-
-
-

100.

\section{E. Downstream Channel Assessment}

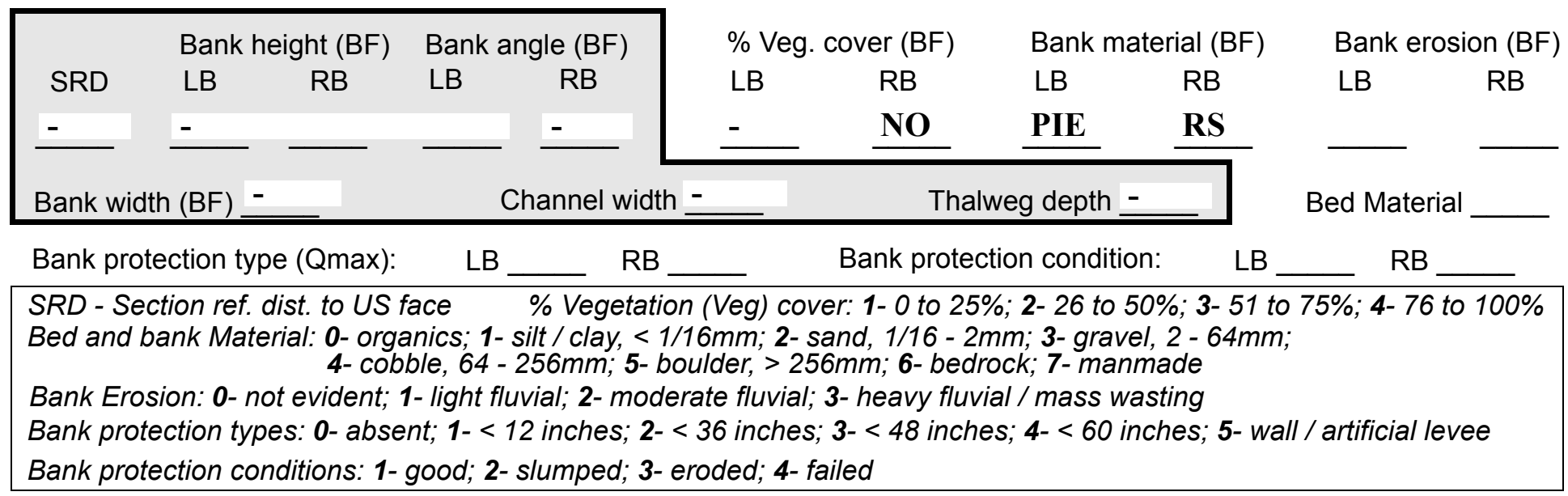

Comments (eg. bank material variation, minor inflows, protection extent, etc.):

1

2

453

432

1

1

435

0

5

1

The right bank protection extends from the DS end of the DS right wingwall to $70 \mathrm{ft}$ DS. It also serves as road approach protection.

101. Is a drop structure present? ___ ( or $N$, if $N$ type ctrl-n ds) 102. Distance: __ feet
103. Drop: - feet
104. Structure material:
(1- steel sheet pile; 2- wood pile; 3- concrete; 4- other)

105. Drop structure comments (eg. downstream scour depth): 
Point bar extent: feet

(US, UB, DS) to $\underline{\mathbf{N}}$ feet (US, UB, DS)

DS) positioned \%LB to DR \%RB

Material: $\mathbf{\text { OP }}$

Point or side bar comments (Circle Point or Side; note additional bars, material variation, status, etc.):

\section{STRUCTURE}

Is a cut-bank present? ( $Y$ or if $N$ type ctrl-n $c b) \quad$ Where? (LB or $R B)$

Mid-bank distance: $\underline{\mathbf{Y}}$

Cut bank extent: 0 feet 8 (US, UB, DS) to $\underline{\mathbf{0}}$ feet $\underline{\mathbf{U S}}$ (US, UB, DS)

Bank damage: 15 (1-eroded and/or creep; 2- slip failure; 3- block failure)

Cut bank comments (eg. additional cut banks, protection condition, etc.):

DS

0

40

345

Is channel scour present? Th (Y or if $N$ type ctrl-n cs) Mid-scour distance: ere is Scour dimensions: Length a Width point Depth: bar Positioned ext \%LB to end \%RB

Scour comments (eg. additional scour areas, local scouring process, etc.):

ing from $20 \mathrm{ft}$ DS to $100 \mathrm{ft}$ DS. Its mid-bar distance is $80 \mathrm{ft}$ DS and the width is $10 \mathrm{ft}$. The material is boulders, cobbles and gravel. The point bar is along the right bank.

Are there major confluences? $\mathbf{N}$ (Y or if $N$ type $c t r l-n m c)$

Confluence 1: Distance Enters on (LB or $R B)$

Confluence 2: Distance -

Enters on ( $L B$ or $R B)$

How many? -

Confluence comments (eg. confluence name):

NO CUT BANKS

\section{F. Geomorphic Channel Assessment}

107. Stage of reach evolution

1- Constructed

2- Stable

3- Aggraded

4- Degraded

5- Laterally unstable

6- Vertically and laterally unstable 
108. Evolution comments (Channel evolution not considering bridge effects; See HEC-20, Figure 1 for geomorphic descriptors):

$\mathbf{Y}$

50

10

5

1.5

0

50

The scour depth is based on a $0.5 \mathrm{ft}$ thalweg. The scour hole is located DS of a large boulder, approximately $6 \mathrm{ft}$ wide.

$\mathbf{N}$ 


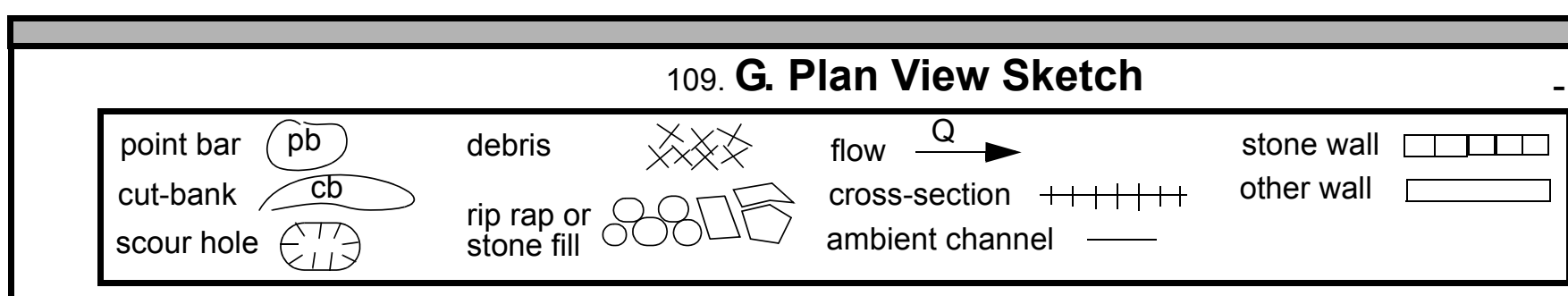


APPENDIX F:

SCOUR COMPUTATIONS 


\begin{tabular}{|c|c|c|c|}
\hline Structure Number: NEWFTH00010008 & & Town : & NEWFANE \\
\hline Road Number: $\quad$ TH 1 & & County: & WINDHAM \\
\hline Stream: WARDSBORO BROOK & & & \\
\hline Initials ECW & Checked: & LKS & \\
\hline alysis of contraction scour, liv & ed or $\mathrm{cl}$ & ear wat & \\
\hline $\begin{array}{l}\text { Critical Velocity of Bed Material } \\
\text { VC=11.21*Y1^0.1667*D50^0.33 with } \\
\text { (Richardson and others, } 1995, \mathrm{p} .\end{array}$ & $\begin{array}{l}\text { converted } \\
=2.65 \\
\text { eq. } 16)\end{array}$ & to Engl & sh units) \\
\hline Approach Section & & & \\
\hline Characteristic & $100 \mathrm{yr}$ & $500 \mathrm{yr}$ & other $\mathrm{Q}$ \\
\hline Total discharge, cfs & 1690 & 2350 & 1120 \\
\hline Main Channel Area, ft2 & 403 & 424 & 308 \\
\hline Left overbank area, ft2 & 8 & 20 & 0 \\
\hline Right overbank area, ft2 & 0 & 0 & 0 \\
\hline Top width main channel, ft & 58 & 58 & 53 \\
\hline Top width L overbank, ft & 23 & 46 & 0 \\
\hline Top width $\mathrm{R}$ overbank, ft & 0 & 0 & 0 \\
\hline D50 of channel, ft & 0.3131 & 0.3131 & 0.3131 \\
\hline D50 left overbank, ft & -- & -- & -- \\
\hline D50 right overbank, ft & -- & -- & -- \\
\hline Y1, average depth, MC, ft & 6.9 & 7.3 & 5.8 \\
\hline Y1, average depth, LOB, ft & 0.3 & 0.4 & ERR \\
\hline $\mathrm{y}_{1}$, average depth, ROB, ft & $\mathrm{ERR}$ & ERR & ERR \\
\hline Total conveyance, approach & 28655 & 31228 & 19374 \\
\hline Conveyance, main channel & 28513 & 30804 & 19374 \\
\hline Conveyance, LOB & 142 & 424 & 0 \\
\hline Conveyance, ROB & 0 & 0 & 0 \\
\hline Percent discrepancy, conveyance & 0.0000 & 0.0000 & 0.0000 \\
\hline Qm, discharge, MC, cfs & 1681.6 & 2318.1 & 1120.0 \\
\hline Q1, discharge, LOB, Cfs & 8.4 & 31.9 & 0.0 \\
\hline Qr, discharge, ROB, cfs & 0.0 & 0.0 & 0.0 \\
\hline $\mathrm{Vm}$, mean velocity $\mathrm{MC}$, ft/s & 4.2 & 5.5 & 3.6 \\
\hline Vl, mean velocity, LOB, ft/s & 1.0 & 1.6 & ERR \\
\hline Vr, mean velocity, ROB, ft/s & $\mathrm{ERR}$ & ERR & $\mathrm{ERR}$ \\
\hline Vc-m, crit. velocity, $M C$, ft/s & 10.5 & 10.6 & 10.2 \\
\hline Vc-l, crit. velocity, LOB, ft/s & ERR & ERR & ERR \\
\hline VC-r, crit. velocity, ROB, ft/s & ERR & ERR & ERR \\
\hline Results & & & \\
\hline Live-bed(1) or Clear-Water(0) Cont & action $\mathrm{Scc}$ & our? & \\
\hline Main Channel & 0 & 0 & 0 \\
\hline Left Overbank & $\mathrm{N} / \mathrm{A}$ & $\mathrm{N} / \mathrm{A}$ & $\mathrm{N} / \mathrm{A}$ \\
\hline Right Overbank & $\mathrm{N} / \mathrm{A}$ & $\mathrm{N} / \mathrm{A}$ & $\mathrm{N} / \mathrm{A}$ \\
\hline
\end{tabular}


Clear water Contraction Scour in MAIN CHANNEL

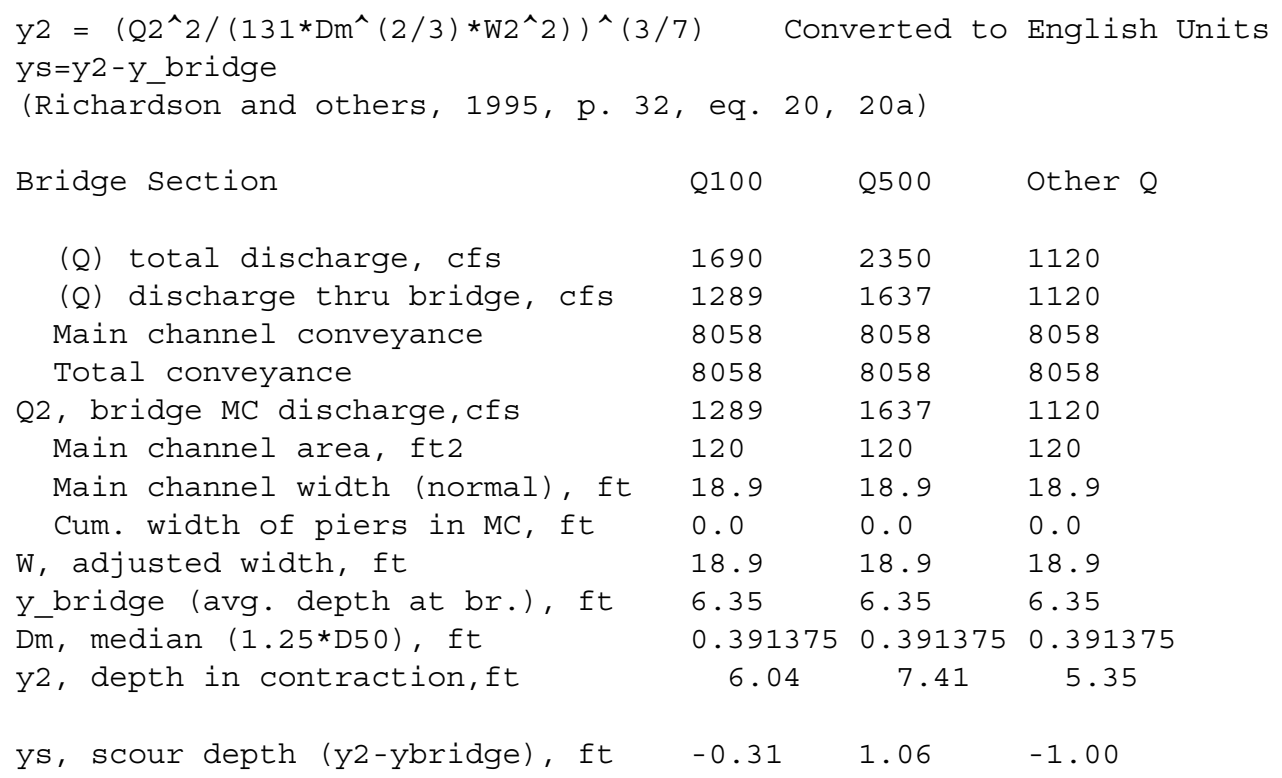

\begin{tabular}{|c|c|c|c|}
\hline \multicolumn{4}{|c|}{ Armoring } \\
\hline \multicolumn{4}{|c|}{$\begin{array}{l}\mathrm{DC}=\left[\left(1.94 * \mathrm{~V}^{\wedge} 2\right) /(5.75 * \log (12.27 * \mathrm{Y} / \mathrm{D} 90))^{\wedge} 2\right] /[0.03 *(165-62.4)] \\
\text { Depth to Armoring }=3 *(1 / \mathrm{PC}-1)\end{array}$} \\
\hline $\begin{array}{l}\text { Depth to Armoring }=3 *(1 / \text { PC-1) } \\
\text { (Federal Highway Administration, } 19\end{array}$ & & & \\
\hline Downstream bridge face property & $100-y r$ & $500-y r$ & Other $\mathrm{Q}$ \\
\hline Q, discharge thru bridge $\mathrm{MC}$, cfs & 1289 & 1637 & 1120 \\
\hline Main channel area (DS), ft2 & 117 & 120 & 99 \\
\hline Main channel width (normal), ft & 18.9 & 18.9 & 18.9 \\
\hline Cum. width of piers, ft & 0.0 & 0.0 & 0.0 \\
\hline Adj. main channel width, ft & 18.9 & 18.9 & 18.9 \\
\hline D90, ft & 0.8085 & 0.8085 & 0.8085 \\
\hline D95, ft & 1.1661 & 1.1661 & 1.1661 \\
\hline Dc, critical grain size, ft & 0.5945 & 0.9014 & 0.6756 \\
\hline Pc, Decimal percent coarser than DC & 0.202 & 0.079 & 0.159 \\
\hline Depth to armoring, ft & 7.06 & & 10.69 \\
\hline
\end{tabular}




\begin{tabular}{|c|c|c|c|c|}
\hline $\begin{array}{l}\text { Chang pressure flow equation } \\
\text { Cq=1/Cf*CC Cf }=1.5 * \mathrm{Fr}^{\wedge} 0.43 \quad(<=1) \\
\text { Umbrell pressure flow equation } \\
(\mathrm{Hb}+\mathrm{Ys}) / \mathrm{Ya}=1.1021 *[(1-\mathrm{w} / \mathrm{Ya}) *(\mathrm{Va} / \mathrm{VC})] \\
\text { (Richardson and other, } 1995, \mathrm{p} .144\end{array}$ & $\begin{array}{l}\mathrm{Hb}+\mathrm{Ys}=\mathrm{C} \\
\mathrm{CC}=\mathrm{SQRT} \\
\wedge 0.6031 \\
-146)\end{array}$ & $\begin{array}{l}\text { * qbr/Vc } \\
0.10(\mathrm{Hb} /\end{array}$ & $(y a-w)-0.56)]+0.79$ & $(<=1)$ \\
\hline & Q100 & Q500 & OtherQ & \\
\hline Q, total, cfs & 1690 & 2350 & 1120 & \\
\hline Q, thru bridge $M C$, cfs & 1289 & 1637 & 1120 & \\
\hline Vc, critical velocity, ft/s & 10.52 & 10.60 & 10.21 & \\
\hline Va, velocity MC approach, ft/s & 4.17 & 5.47 & 3.64 & \\
\hline Main channel width (normal), ft & 18.9 & 18.9 & 18.9 & \\
\hline Cum. width of piers in MC, ft & 0.0 & 0.0 & 0.0 & \\
\hline W, adjusted width, ft & 18.9 & 18.9 & 18.9 & \\
\hline qbr, unit discharge, ft2/s & 68.2 & 86.6 & 59.3 & \\
\hline Area of full opening, ft2 & 120.0 & 120.0 & 120.0 & \\
\hline $\mathrm{Hb}$, depth of full opening, ft & 6.35 & 6.35 & 6.35 & \\
\hline Fr, Froude number, bridge MC & 0.9 & 1.14 & 0.78 & \\
\hline Cf, Fr correction factor $(<=1.0)$ & 1.00 & 1.00 & 1.00 & \\
\hline **Area at downstream face, ft2 & 117 & $\mathrm{~N} / \mathrm{A}$ & 99 & \\
\hline **Hb, depth at downstream face, ft & 6.19 & $\mathrm{~N} / \mathrm{A}$ & 5.24 & \\
\hline **Fr, Froude number at DS face & 0.78 & ERR & 0.87 & \\
\hline$* * \mathrm{Cf}$, for downstream face $(<=1.0)$ & 1.00 & $\mathrm{~N} / \mathrm{A}$ & 1.00 & \\
\hline Elevation of Low steel, ft & 495.09 & 495.09 & 495.09 & \\
\hline Elevation of Bed, ft & 488.74 & 488.74 & 488.74 & \\
\hline Elevation of Approach, ft & 499.94 & 500.3 & 498.23 & \\
\hline Friction loss, approach, ft & 0.14 & 0.23 & 0.12 & \\
\hline Elevation of WS immediately US, ft & 499.80 & 500.07 & 498.11 & \\
\hline ya, depth immediately US, ft & 11.06 & 11.33 & 9.37 & \\
\hline Mean elevation of deck, ft & 501.3 & 501.3 & 501.3 & \\
\hline w, depth of overflow, ft $(>=0)$ & 0.00 & 0.00 & 0.00 & \\
\hline Cc, vert contrac correction $(<=1.0)$ & 0.83 & 0.80 & 0.90 & \\
\hline$* * C \mathrm{C}$, for downstream face $(<=1.0)$ & $\mathrm{ERR}$ & ERR & ERR & \\
\hline Ys, scour w/Chang equation, ft & 1.49 & 3.90 & 0.11 & \\
\hline Ys, scour w/Umbrell equation, ft & 0.63 & 2.02 & -0.81 & \\
\hline
\end{tabular}




\begin{tabular}{|c|c|c|c|}
\hline \multicolumn{4}{|c|}{$\begin{array}{l}\text { In UNsubmerged orifice flow, an adjusted scour depth using the Laursen } \\
\text { equation results and the estimated downstream bridge face properties } \\
\text { can also be computed (ys=y2-ybridgeDS) }\end{array}$} \\
\hline y2, from Laursen's equation, ft & 6.04 & 7.41 & 5.35 \\
\hline WSEL at downstream face, ft & 494.97 & -- & 493.97 \\
\hline Depth at downstream face, ft & 6.19 & $\mathrm{~N} / \mathrm{A}$ & 5.24 \\
\hline Is, depth of scour (Laursen), ft & -0.15 & $\mathrm{~N} / \mathrm{A}$ & 0.11 \\
\hline
\end{tabular}

Abutment scour

Froehlich's Abutment Scour

$\mathrm{Ys} / \mathrm{Y} 1=2.27 * \mathrm{~K} 1 * \mathrm{~K} 2 *\left(\mathrm{a}^{\prime} / \mathrm{Y} 1\right)^{\wedge} 0.43 * \mathrm{Fr} 1^{\wedge} 0.61+1$

(Richardson and others, 1995, p. 48, eq. 28)

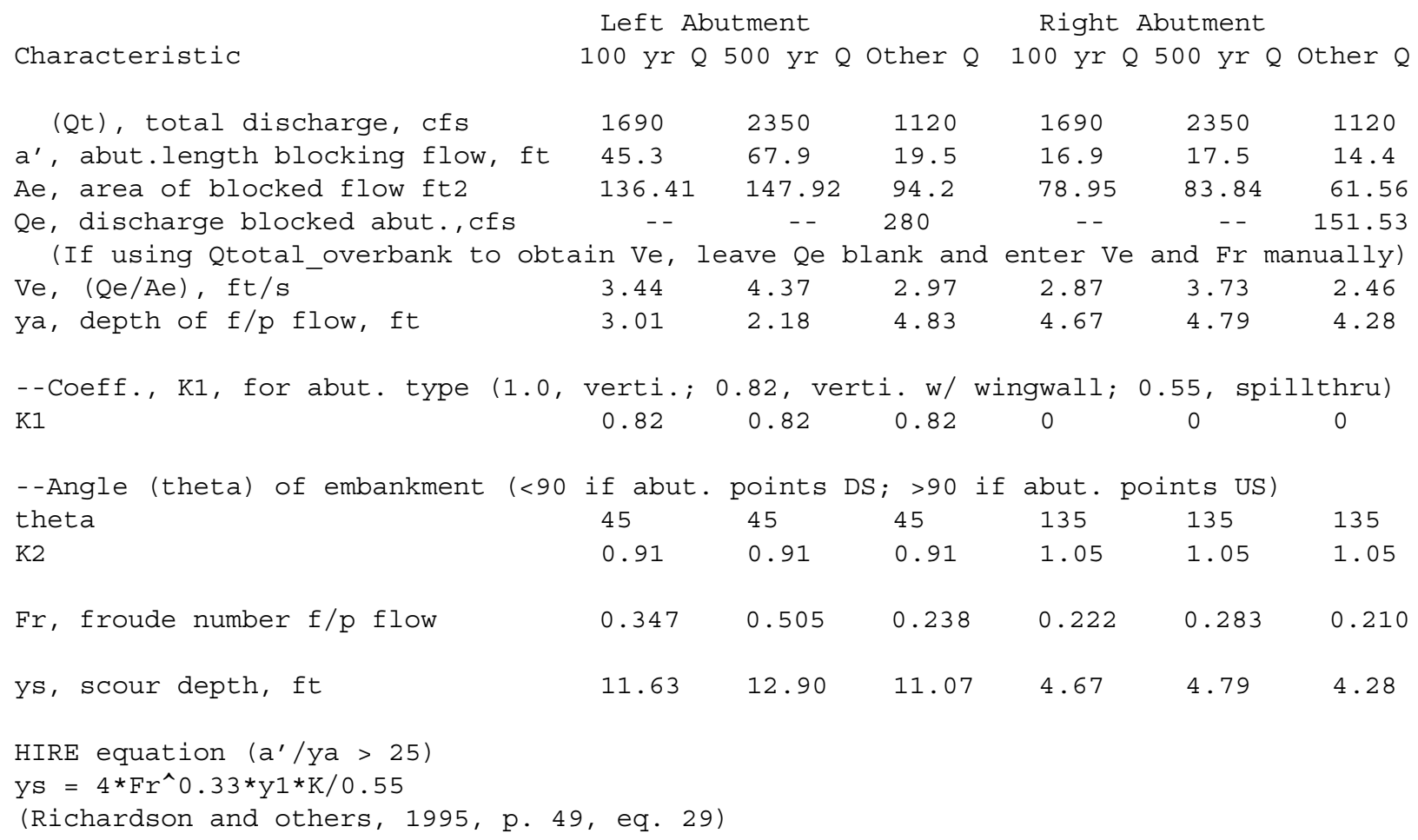




\begin{tabular}{|c|c|c|c|c|c|c|}
\hline a' (abut length blocked, ft) & 45.3 & 67.9 & 19.5 & 16.9 & 17.5 & 14.4 \\
\hline y1 (depth f/p flow, ft) & 3.01 & 2.18 & 4.83 & 4.67 & 4.79 & 4.28 \\
\hline$a^{\prime} / y^{\prime}$ & 15.04 & 31.17 & 4.04 & 3.62 & 3.65 & 3.37 \\
\hline Skew correction (p. 49, fig. 16) & 0.80 & 0.80 & 0.80 & 1.10 & 1.10 & 1.10 \\
\hline Froude no. f/p flow & 0.35 & 0.51 & 0.24 & 0.22 & 0.28 & 0.21 \\
\hline $\begin{array}{c}\text { Ys w/ corr. factor } \mathrm{K} 1 / 0.55: \\
\text { vertical }\end{array}$ & ERR & 10.12 & ERR & ERR & ERR & ERR \\
\hline vertical w/ ww's & ERR & 8.30 & ERR & $\mathrm{ERR}$ & ERR & ERR \\
\hline spill-through & ERR & 5.56 & ERR & ERR & ERR & ERR \\
\hline Abutment riprap Sizing & & & & & & \\
\hline Isbash Relationship & & & & & & \\
\hline $\begin{array}{l}\mathrm{D} 50=\mathrm{Y} * \mathrm{~K} * \mathrm{Fr} r^{\wedge} 2 /(\mathrm{Ss}-1) \text { and } \mathrm{D} 50=\mathrm{Y} * \mathrm{~K} *( \\
\text { (Richardson and others, 1995, p11 }\end{array}$ & $\begin{array}{l}\wedge \\
2)^{\wedge} 0 \\
\text { eq. }\end{array}$ & $\begin{array}{l}(S s-1) \\
2)\end{array}$ & & & & \\
\hline Characteristic & Q100 & Q500 & Other $Q$ & Q100 & Q500 & Other Q \\
\hline Fr, Froude Number & 0.78 & 1 & 0.87 & 0.78 & 1 & 0.87 \\
\hline$y$, depth of flow in bridge, ft & 6.19 & 6.35 & 5.24 & 6.19 & 6.35 & 5.24 \\
\hline Median Stone Diameter for riprap & $:$ left & utment & & right & abutment, & ft \\
\hline Fr<=0.8 (vertical abut.) & 2.33 & ERR & ERR & 2.33 & ERR & ERR \\
\hline Fr>0.8 (vertical abut.) & ERR & 2.66 & 2.11 & $\mathrm{ERR}$ & 2.66 & 2.11 \\
\hline
\end{tabular}

